UDK: 28::347.6-055.2

Izvorni naučni rad

Prof. dr. Muharem Štulanović, redovni profesor

Univerzitet u Bihaću

Islamski pedagoški fakultet

ebuseba@hotmail.com

\title{
PORODIČNO PRAVO I REVOLUCIONARNI DOPRINOS ISLAMA STATUSU ŽENE
}

\section{Sažetak}

Porodično pravo možemo tretirati kao granu pozitivnog prava i kao zaseban, samostalan dio pravne nauke.

Porodično pravo predstavlja skup pravnih normi kojima se reguliše porodica $i$ odnosi izmedu članova porodice, odnosno regulišu se odnosi koji nastaju prilikom formiranja porodice, njenog trajanja ili prestanka postojanja. Ovi odnosi nastaju zasnivanjem veze muškarca $i$ žene, radanja i oblicima srodstva koji proizilaze iz te veze.

Teoretičari prava u islamskoj kulturi i civilizaciji uobičajili su termin porodičnog prava za regulativu koja se tiče braka, razvoda, testamenta $i$ nasljedivanja, iako je u islamskom fikhu, ranije, sve ono što reguliše porodične odnose nazivano ličnim, posebnim imenom kao što je poglavlje o braku, razvodu isl.

Islam je prema ženi donio revolucionarno poboljšanje njenog statusa, u smislu primjene ljudskih prava $i$ dokidanja dotadašnjih običaja koji su je diskriminirali jer je Uzvišeni Allah odlikovao i oplemenio ljudski rod, oba njegova dijela, ženski i muški, čije veze je regulirao propisima koji se odlikuju svojim specifićnostima i vrijednostima.

Reformska načela sa kojima je došao islamski sistem, posebno ona koja se tiču statusa žene i njene uloge u društvu, ogledaju se u mnogobrojnim aspektima $i$ mogu se konkretizovati kroz socijalnoldruštveni, humanilljudski $i$ pravno/šerijatski aspekt.

Ključne riječi: Porodično pravo, islamsko porodično pravo, status žene, porodica, brak, vanbračna zajednica, biseksualni i istospolni brakovi, prava žene, diskriminacija žene. 


\section{Uvod}

Porodično pravo je i posebna naučna, pravna disciplina. Ona se bavi naučnom sistematizacijom pravnih normi, njihovim grupisanjem $u$ pravne institute otkrivanjem zajedničkih načela i kritičkim razmatranjem i pravnim apstrahiranjem i promišljanjem u iznalasku odgovarajućih pravnih rješenja.

Predmet porodičnog prava su porodičnopravni odnosi članova jedne porodice. Adresati i subjekti porodičnih odnosa, imaju različit položaj i ulogu (supružnici, roditelji, djeca, srodnici) tokom svog odrastanja i života. Jedno isto fizičko lice tokom svoga života može imati različite uloge i položaj. Tako, samim rođenjem, dijete stiče određena prava u odnosu na roditelje, dok se u drugim slučajevima od njih zahtijeva određen uzrast ili sposobnost kao u slučaju zaključenja braka ili kod usvajanja u konvencionalnom pravu.

Bračno pravo uređuje pitanja sklapanja, dejstva i prestanka braka. U posljednje vrijeme, ovdje spadaju i pitanja vezana za vanbračnu zajednicu, a u novije doba pod utjecajem i diktatom međunarodnih faktora u pogledu zaštite ljudskih prava LGBT osoba traži se usklađivanje postojećeg zakonodavnog okvira u BiH sa Zakonom o zabrani diskriminacije koji je donesen 2009. godine što se reflektuje na pitanje i pokušaje izjednačavanja istospolnih brakova sa biseksualnim.

Argumenti koji su uslovili izdvajanje ili osamostaljivanje porodičnog od građanskog prava leže u činjenici da porodično pravo reguliše pretežno lične odnose, a građansko pravo imovinske.

Kogentni (prinudni) karakter normi porodičnog prava uređuje se pretežno dispozitivnim normama, odnosno stranke svojom voljom regulišu međusobne odnose. A tek, ako to ne učine, primijeni se pravilo iz pravne norme. Ipak, moguće je da se voljom, ugovorno, uredi i sadržina porodičnih odnosa, ličnih i imovinskih (pokloni, testament i sl.). Zbog prirode i karaktera ovih odnosa zasnovanih na osjećanjima ljubavi, naklonosti, prijateljstva, izvršavanje porodičnopravnih obaveza, ne može se obezbjediti direktnom sankcijom, kao u slučaju građanskog prava. Naravno, ovo se odnosi na konvencionalno pravo, međutim, šerijatsko porodično pravo regulira i ove ,pravne“ odnose.

$\mathrm{U}$ BiH kao i u zemljama regiona, vidljiv je utjecaj međunarodne zajednice i njenih pravnih normi na lokalna zakonodavstva, kao i utjecaj 
politike i globalnih evroatlanskih integracija nametanjem normi koje u nekim slučajevima zadiru u samu bit i srž dosadašnjih pravnih shvatanja i terminoloških određenja. To je slučaj i u ovoj grani pravne znanosti. Akti i konvencije međunarodnog prava postaju izvori porodičnog prava određene zemlje ukoliko ih je ratifikovao njen zakonodavni organ $\mathrm{i}$ nakon stupanja na snagu.

Općepoznati međunarodni akti koji su izvori porodičnog prava, preuzeti su gotovo bez ikakvih izmjena u zakonodavstvo zemalja našeg regiona - okruženja:

1. UN su usvojile Univerzalnu deklaraciju, 1948. godine, o pravima čovjeka u kojoj se štiti i pravo punoljetnih muškaraca i žena da bez ikakvih ograničenja u pogledu državljanstva ili vjeroispovjesti, zaključuju brak i zasnivaju porodicu (čl. 16.).

2. Kasnije su usvojeni i Međunarodni pakt o ekonomskim, socijalnim i kulturnim pravima i Međunarodni pakt o građanskim i političkim pravima, koji uglavnom ponavljaju odredbe o braku i porodici koje su već postojale u Deklaraciji, ali sada sa obavezujućim dejstvom za države koje su ih ratifikovale.

Pored ovih dokumenata, od strane Generalne skupštine UN, usvojeni su i drugi dokumenti značajni za porodično pravo, kao što su konvencije o:

- zaštiti materinstva,

- ostvarivanju alimentacionih zahtjeva u inostranstvu,

- državljanstvu udatih žena,

- pristanku na brak, o minimalnoj dobi za brak i za registraciju braka,

- eliminisanju svih oblika diskriminacije žena,

- zaštiti ljudskih prava i osnovnih sloboda koja je usvojena 1950. godine u Rimu. Za porodično pravo naročito značajni su član 8 . (pravo na poštovanje privatnog i porodičnog života) i $u$ izvjesnoj mjeri čl. 12. (pravo na brak i zasnivanje porodice),

- pravima djeteta iz 1989. godine, djetetu priznaje pravni status koji obuhvata posebna prava. 


\section{Porodično pravo u islamu}

Uticajem konvencionalnog zakonodavstva i u islamskom pravu došlo se do upotrebe termina islamsko porodično pravo. A u islamskoj metodologiji prava, poznato je pravilo Nema rasprave i razilaženja $u$ pitanjima terminologije, kojim se dozvoljava upotreba određenih termina, pod dva uvjeta:

1. da novi termin zadovoljava naučni okvir određenog značenja i

2. da nije u koliziji sa šerijatskim značenjem koje bi ga poništavalo.

Odabrano terminološko značenje islamskog porodičnog prava, može se definirati da je:

skup onoga čime se odlikuje čovjek prirodnim ili porodičnim osobinama koje uređuje zakon, a koje uzrokuju pravno dejstvo u društvenom životu, kao što je njegova priroda da je muško ili žensko, supružnik, udovica, raspuštenica, otac, ili da ima punu poslovnu sposobnost, ili djelimičnu zbog maloljetstva ili ludosti, da može neograničeno poslovati ili sa zakonskim ili šerijatskim ograničenjima.

U historijskom smislu islamsko porodično pravo primjenjivano je $\mathrm{u}$ sudskoj praksi stoljećima. Tek početkom dvadesetog vijeka, nakon kolonizacije arapskog islamskog svijeta od strane Engleske i Francuske dolazi do upotrebe samog termina porodičnog prava pod utjecajem konvencionalnog evropskog prava. Dakle, tek $\mathrm{u}$ prvoj polovici dvadesetog vijeka, dolazi do upotrebe ovog termina, posebno u Iraku, da bi se na kraju u islamskom svijetu došlo do izrade posebnog porodičnog zakona 1959. g.

\section{Važnost braka u islamskoj doktrini}

Važnost koju Šerijat pridaje ovoj instituciji ogleda se i u tome da podjela šerijatskog prava kod nekih i sl. klasičara ide na četiri oblasti:

1. ibadat (obredoslovlje), dakle dio koji govori i sadrži propise o obredima, tj. regulira odnos čovjeka i njegovog Stvoritelja.

Ostalo je vezano za propise koji reguliraju korelacijske veze među ljudima kroz sljedeće oblasti:

2. mu'amelat, (civilno ili građansko pravo), 
3. i ukubat (krivično i kazneno pravo),

4. munakehat, (bračno pravo).

Uzvišeni Bog stvorio je sva živa stvorenja: životinje, biljke, insanačovjeka u paru; uvid u muškog i ženskog pola.U Kur'anu se kaže:

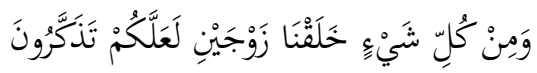

I od svega po par stvaramo da biste vi razmislili. (Kur'an, Ez-Zarijat, 49.)

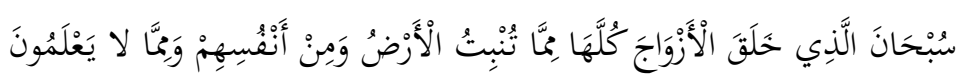

Neka je hvaljen Onaj koji u svemu stvara pol: u onome što iz zemlje niče, u njima samim, i u onome što oni ne znaju.(Kur'an, Ja-Sin, 36.)

To je prirodni zakon koji je Bog stvorio za obnavljanje i reprodukciju iz parova.

Zatim je u prirodi kod oba spola stvorio osjećaje i naklonost jednih prema drugima. Rezultat toga je porod kroz instituciju braka čime se produžava opstanak vrste na zemlji do momenta koji je propisan i određen kao Smak svijeta u kome će se desiti uništenje ovodunjalučkog, stvorenog svijeta.

Uzvišeni Gospodar je „odlikovao čovjeka", jer se to navodi u Kur'anu:

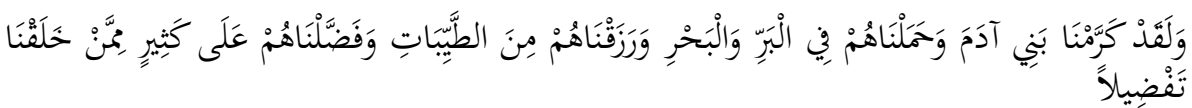

Mi smo sinove Ademove doista odlikovali: dali smo im da kopnom $i$ morem putuju, i opskrbili ih ukusnim jelima i dali im velike prednosti nad mnogima koje smo stvorili. (Kur'an, El-Isra', 70)

Kada Uzvišeni kaže: Mi smo sinove Ademove, doista, odlikovali..., onda produžetak njegove ljudske vrste nije prepustio samo instinktu održanja, kao, recimo, što je slučaj kod životinja, ptica i sl., nego je propisao način na koji će ljudi regulirati bračne odnose.

Uzvišeni se obraća Poslaniku, a.s., i kaže mu:

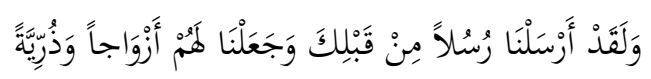

I prije tebe smo poslanike slali $i$ žene i porod im davali... (Kur'an, ErRa'd, 38.) 
Svi Božiji poslanici i vjerovjesnici su se ženili. Historičari bilježe samo da se Jahja i Isa, a.s., nisu ženili. Isa se nije oženio zbog nemorala njegovih sunarodnica pa se zbog toga posvetio samo ibadetu. Međutim, u Gazalijevom „Ihjau u'lumid-din" spominje se da će se i on oženiti kada ponovno bude spušten na zemlju $(4,97$.$) .$

\section{Odlike islamskog pogleda na brak}

Islam je posvetio posebnu pažnju bračnom sporazumu i ugovoru dajući mu posebnu ulogu između ostalih ugovora koji se sklapaju zbog svih posljedica koje prouzrokuje ne samo kod onih koji su neposredni sudionici ugovora, nego i kod njihovih porodica i čitavog društva.

To je, možda, najznačajniji ugovor koji čovjek sklopi u svome životu.

Zbog toga se Zakonodavac u islamu pobrinuo da dā propise o ženidbi koji reguliraju materiju bračnog prava od samog početka razmišljanja o toj temi pa do smrti ili rastave.

Ondje gdje ne funkcionira brak i gdje je zanemaren, javljaju se razne nastranosti koje rezultiraju negativnim posljedicama i bolestima pojedinca i društva.

Celibat-neženstvo nije bio propisan ni u jednoj nebeskoj vjeri. U kršćanstvu postoji ali to je izum kršćanske crkve.

Kur'an o tome obavještava:

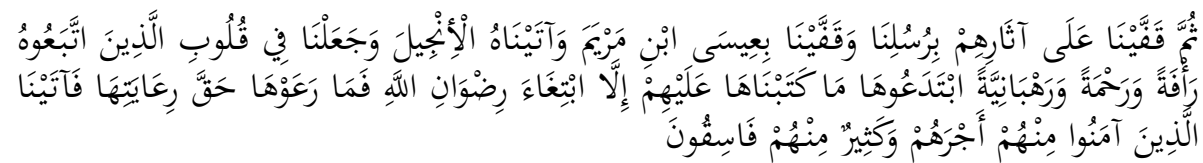

Zatim smo, poslije njih, jednog za drugim poslanike slali Naše, dok nismo Isaa, sina Merjemina, poslali, kojem smo Indžil dali, a u srca sljedbenika njegovih blagost smo i samilost ulili dok su monaštvo, oni sami, kao novotariju uveli. - Mi im ga nismo propisali u želji da se stekne Allahovo zadovoljstvo; ali oni o njemu ne vode brigu onako kako bi trebalo, pa ćemo one među njima koji budu ispravno vjerovali nagraditi, a mnogi su od njih nevjernici.(Kur'an, El-Hadid, 27.)

Ibni Kesir smatra da su spomenuto monaštvo kršćani izmislili i uveli kao novotariju pridržavajući ga se, iako im Bog to nije propisao. 
On im je propisao da stiču Njegovo zadovoljstvo. Međutim, oni se nisu odazvali ni onome na što su se sami obavezali.

Ovim ajetom Allah ih kori na dva načina:

\section{1. za izmišljanje novotarije u vjeri koju Bog nije naredio i}

2. za neodazivanje onome što su se obavezali tvrdeći da je to dobročinstvo kojim se približava Bogu.

Celibat ili neženjenje je neprirodan i čak protuvjerski čin.

Zato on sa sobom nosi stalne probleme i stalne afere koje potresaju Crkvu u vidu pedofilije (seksualna nastranost $\mathrm{i}$ iskorištavanje djece $\mathrm{u}$ seksualne svrhe), homoseksualizma, sodomije i drugih nastranostiperverzija, koje se mogu spriječiti samo normalnim brakom, odnosno zadovoljavanjem strasti na prirodan način.

U savremeno doba mnoga „napredna" zakonodavstva imaju intenciju da idu za dozvolom svih nastranosti i perverzija koje prate moralni pad zapadnog čovjeka. Time zapadna civilizacija narušava brak i instituciju braka koja je uvjet za opstanak čovjeka na zemlji i njegovu reprodukciju.

Nasuprot svega ovoga propisi islama, njegove norme, ibadeti (obredoslovlje) imaju svevremenu aktualnost, svrhovitost, mudrost i nadnaravan, božanski karakter.

I to se može zapaziti kod jednog ozbiljnog naučnog pogleda i pristupa $\mathrm{u}$ razumijevanju vjere i njenih sastavnih ibadetskih (obredoslovnih) aktivnosti, a posebno u pogledu braka i njegovih propisa.

\section{Revolucionarno, historijsko poboljšanje statusa i uloge žene u islamu}

Historijski gledano, krajem šestog stoljeća po rođenju Isaa, a.s., usred džahilijetskog mračnjaštva i odnosa spram žene u tadašnjim pravnim običajima Arapskog poluotoka, dolazi Božija objava koja će dati ženi njena prava shodno njenom dostojanstvu i njenoj ulozi kao ljudskog bića.

To je bio revolucionarni napredak i ustrojavanje Božanskog sistema koji daje svim adresatima njihova prava bez manjkavosti, a u pogledu 
žene dokida nepravdu i poniženje kojima je ona bila izložena tokom cijele ranije historije čovječanstva.

Uzvišeni Allah je odlikovao i oplemenio ljudski rod, žensko i muško, čije veze je regulirao neprevaziđenim porodičnim vezama i propisima, odlikovanim nekim specifičnostima i vrijednostima, koje uzimaju u obzir njihove ljudske i spolne karakteristike:

1. Obaveza (teklif) sa šerijatkim propisima obuhvata muško i žensko, osim ako nekog od njih izuzima u nekom određenom diskrecionom segmentu, kao što je obaveza izdržavanja koja pada na supruga, dok je propis menstrualnog ciklusa vezan samo za žensko.

2. Princip jednakosti u obavezama i pravima, osim u nekim slučajevima u kojima je specificirano suprotno kao diskreciono pravo jedne od dvije grupacije, na što upućuju riječi Uzvišenog:

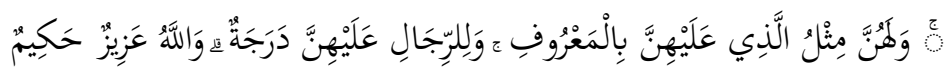

One imaju isto toliko prava koliko i dužnosti, prema zakonu - samo, muževi imaju prednost pred njima za jedan stepen. - A Allah je silan $i$ mudar. (Kur'an, El-Bekare, 228.)

Stepen/deredža spomenuta u ajetu ima dva interaktivna značenja. Suprug ima mogućnost i diskerciono pravo razvoda i drugo njegov stepen nije u smislu vrednovanja i vrijednosti nego je to faktički stepen obaveze koju zahtijeva specifičnost Božijeg stvaranja čovjeka u paru.

\section{Status žene $\mathbf{u}$ islamskom šerijatskom pravu}

Ako se historijski vratimo na početak objave islama, primjećujemo da je Uzvišeni Bog objavio i poslao čovječanstvu, ne samo vjeru kao jedan vid duhovne nadgradnje i duhovne potrebe, nego i pravni sistem Šrerijata da ga primjenjuje i sprovodi u praksu. I On najbolje zna šta odgovara čovjeku i ženi, njihovoj ljudskoj prirodi, kao i to šta je najbliže pravdi koja treba da zadovolji sve strane.

Onaj ko ne boluje od predrasuda, lahko će uočiti nadnaravnost $\mathrm{u}$ različitim aspektima islama kao doktrine i Šerijata kao njegovog pravnog sistema ili poretka.

O Šerijatu vladaju pogrešne predrasude kao o sistemu koji je krut, nefleksibilan, nepravedan, zaostao, i nadasve, sistem koji je u domenu 
ljudskih prava posebno obespravio ženu. S druge strane, poznata su i savremena stajališta o ženi, pokret feminizma i emancipacije žene koji vode u drugu krajnost.

Žena se nastoji emancipirati po nekim uzusima savremenih neetičkih ideologija. Međutim, u toj prividnoj emancipaciji žene, kao jedinstvenog, humanog bića ona je izigrana i obmanuta, jer joj se $u$ krajnjoj konsekvenci i udovoljenju ciljevima materijalističkog konzumerizma želi podvaliti i obezvrijediti je tretmanom objekta za najveću savremenu industriju koja donosi basnoslovnu zaradu. Naime, savremena emancipacija žena umjesto da uzme u obzir njenu jedinstvenu ulogu, koju niko drugi ne može zamijeniti, niti odigrati $u$ historiji čovječanstva, njegovog opstanka i reprodukcije, podrazumijeva njeno savremeno porobljavanje, robovanje strastima $\mathrm{i}$ jednoj od najvećih ,industrija" savremenog doba, umjesto da joj olakša njenu ulogu žene nameće joj se još i ulogu koja ide u pravcu izjednačavanja sa muškarcem $u$ teškim poslovima i fizičkim obavezama, svodeći je na robu koju se može kupiti. Kao što se kupuje $\mathrm{kg}$. šećera, kahve, banana. Tako se u ovoj eri tzv. kvazi slobode i sveopćeg konzumerizma, žena jednostavno može kupiti kao tijelo, razgolićena i naravno potpuno obezvrjeđena, jer se time spustila na nivo vrijednosti potrošne robe. Pa se za novac može dobiti "kilogram" pornografije, žensko tijelo itd.

Zar je to ženska emancipacija? I jesu li to principi, vrijednosti i domen koji su dosegli savremeni borci za ljudska prava i žensku emancipaciju! Zašto žene pristaju na takav vid ponižavanja i obezvrjeđivanja?

Zašto se žene ne pobune protiv iskorištavanja njihovog tijela dominantno u svrhu zabave, industrije, pornografije, i sl.?

Zašto žene i ženska udruženja, ne štite integritet žene, žene-majke, žene koja ima i drugih vrijednosti, a ne samo tijelo, zašto se ne bore protiv pornografije u medijima, zašto ne ustaju protiv iskorištavanja žene, prodaje ženskog tijela i sl.?

Iz iskustva se vidi da na Zapadu a i kod nas, to susrećemo na svakom koraku, što upućuje, ili da se njihov glas ne čuje, ili da su neefikasni.

Kojom logikom brane vidove nemorala govoreći da je to umjetnost?! 
Ako neko smatra da je skidanje i ekshibicionizam, javno pred svima i pred kamerama, vrijednost, pa da li bi pristao da mu mati, ili žena, ili sestra, ili kćerka hoda gola po ulici, pojavi se takva pred kamerama i sl.

Islam vrednuje ženu kao najveće dunjalučko blago i u tom smislu to je bio revolucionarni napredak tretmana žene $u$ dotašnjim svjetskim, vladajućim, pravnim običajima o čemu se može autoritativno govoriti kroz tekstove tradicionalnih izvora islama. Dakle, islam oslobađa ženu i revolucionarno mijenja njen položaj i status na bolje, jer je u džahilijetskom, predislamskom vremenu i društvu njen položaj bio nedostojan, ropski i ona je kao član zajednice i društva bila obespravljena.

A da bi razumjeli revolucionarno poboljšanje statusa žene kojeg je dobila islamom, moramo se prvo podsjetiti koliko je žena bila obespravljena u paganskom, džahilijetskom, predislamskom društvu.

\section{Dokidanje običaja zakopavanja žive ženske djece}

Žena je u predislamskom, džahilijetskom društvu bila obespravljena. Koliko je bila obespravljena govori činjenica da su predislamski Arapiima ijedan barbarski, paganski običaj zakopavanja žive ženske djece, prakticiran sve do pojave Muhammeda, a.s., koji je od Allaha, Gospodara kosmosa, Gospodara zemlje, nebesa i svega drugog, poslan da to zabrani.

UtefsiruIbn-Kesirana vodi se slučaj Kajsb Asima koji je došao Allahovom Poslaniku, a.s., i rekao: „Allahov Poslaniče, u džahilijetu sam sahranio osam živih djevojčica." ${ }^{\text {1 }}$

Međutim, usprkos ovakvim slučajevima, islam je,kao nenadmašni,božanski sistem življenja, čak i od takvih bezosjećajnih, brutalnih ljudi iskova najplemenitije i najčasnije ashabe.

Koje to čudovište može biti čovjek, i kakvo to kameno srce može da zakopa svoje živo čedo samo zato što nije sin koji može uzeti sablju i ratovati.

${ }^{1}$ Tefsir Ibn Kesir, skraćeno izdanje, Muhammed Nesib Er-Rifa'i, (Sarajevo, 2000), 1476. 
Dakle, koliko je to bilo gnusno i koliki je to zulum bio uvid u to govori činjenica da je Uzvišeni Bog intervenirao, zabranio i zaštitio ženu slanjem Poslanika, a.s., sa novim pravnim poretkom koji će ženi vratiti dostojanstvo i dati joj ljudska prava.

Kur'an ovaj ružni običaj spominje kroz dva ajeta koji su toliko upečatljivi, dani štaviše nije objavljeno u Kur'anu, bilo bi dovoljno da se vjeruje Dragog Allaha i prihvati Kur'an kao istina.

Uzvišeni Allah opisujući Sudnji dani i strah od ovozemaljskog i kosmičkog kolapsa, nakon toga kaže:

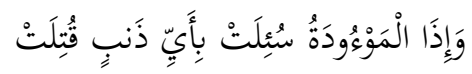

i kada živa sahranjenā djevojčica bude upitana, zbog kakve krivice je umorena. (Kur'an, El-Tekvir, 8-9.)

Kur'an je ovdje u nenadmašnom božanskom izrazu: - I kada živa sahranjena djevojčica bude upitana - upotrijebio pasiv u značenju da će umorena, nevina, bezgriješna djevojčica biti pitana.

Poznato je, psihološki, da se potpuno nevin čovjek, kao i čovjek koji traži svoje pravo na sudu, nelagodno osjećaju na sudu iako potražuju svoje pravo, jer bivaju pitani.

Prema tome, kada je činjenica da će i umorena, nevina, bezgriješna djevojčica biti pitana $i$ saslušavana, pa kako će tek biti pitani i isljeđivani, i konačno kažnjeni oni koji su ih bespravno ubijali. Ovakav kur'anski izraz je, ustvari, prijetnja koja se izražava na ovakav implicitan, metaforičan, božanski, nenadmašan način.

To nepojmljivo zvijerstvo Uzvišeni naziva gubitkom koji će sigurno dovesti do zablude i stradanja:

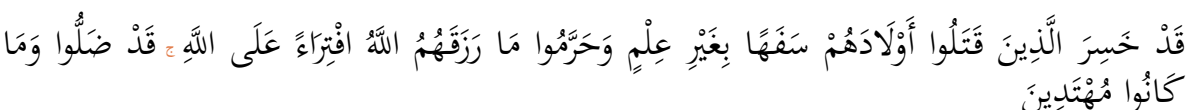

Oni koji iz lahkoumnosti i ne znajući šta rade djecu svoju ubijaju i koji ono čime ih je Allah podario zabranjenim smatraju, govoreći neistine o Allahu, sigurno će nastradati. Oni su zalutali i oni ne znaju šta rade. (Kur'an, El-En'am, 140.)

A Muslim (593.) je zabilježio predaju od Mugire b. Šu’be, r.a., koji pripovijedada je Allahov Poslanik, s.a.v.s., rekao: 


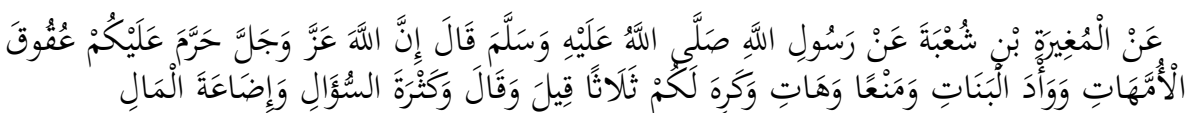

Allah, dž.š., zabranio vam je neposlušnost vašim majkama, ,ne dam, a daj " (ne da ono što mu je dužnost, a uzima ono što mu nije dozvoljeno) i zakopavanje žive ženske djece, a pokudio troje: „rekla - kazala“, prekomjerno zapitkivanje i upropaštavanje imovine.

Prema svemu ovome, očito je da se u islamskim tradicionalnim izvorima nalaze mnogobrojni tekstovi koji inzistiraju na dobročinstvu i lijepom odnosu prema ženskom djetetu, posebno, dokidajući džahilijetski zulum, nepravde, stereotipe, predrasude i neprimjerene postupke prema ženskoj djeci, samo iz razloga što su ženska bića, a sve to s ciljem da se to žensko, ljudsko biće razvije i formira kao dobra $\mathrm{i}$ čestita majka koja će voditi računa o ispravnom islamskom odgoju svoje djece.

Da bi iskorijenio predislamski običaj mržnje i averzije prema ženskoj djeci, Allahov je Poslanik, s.a.v.s., roditelje podsticao na lijep odnos prema njima, tražeći i stimulirajući na njihovo izdržavanje, njegovanje i odgajanje od njihovog rođenja, pa sve dok ne odrastu, ne udaju se i osamostale.

\section{Jednakost spolova po prirodi stvaranja}

Žena je po svojoj prirodi stvaranja jedna od dvije ljudske jedinke čija ravnopravnost $\mathrm{u}$ principu izvire iz jednakosti njihovog pripadanja ljudskom rodu, istoj vrsti, a njihove međusobne razlike izviru iz mudrosti Uzvišenog Kreatora, koji im dade različite uloge $u$ ovosvjetskom životu koje su uslovljene biološkom potrebom različitosti. Uzvišeni obavještava:

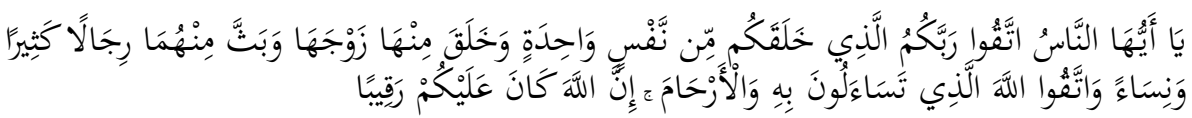

O ljudi, bojte se Gospodara svoga, koji vas od jednog čovjeka stvara, a od njega je i drúgu njegovu stvorio, i od njih dvoje mnoge muškarce $i$ žene rasijao. (Kur'an, En-Nisa', 1.)

Ta jednakost muškaraca i žena proteže se na njihovu zajedničku svrhu i bit stvaranja, a to je da budu u pokornosti jednom, jedinom Bogu, da Ga obožavaju i postignu Njegovu blizinu, imaju iste dužnosti prema 
Bogu i prema Njegovim stvorenjima kao i pravo na istu nagradu, koju Uzvišeni eksplicitno spominje, kako za kategorije vjernika isto tako identično i za kategorije vjernica:

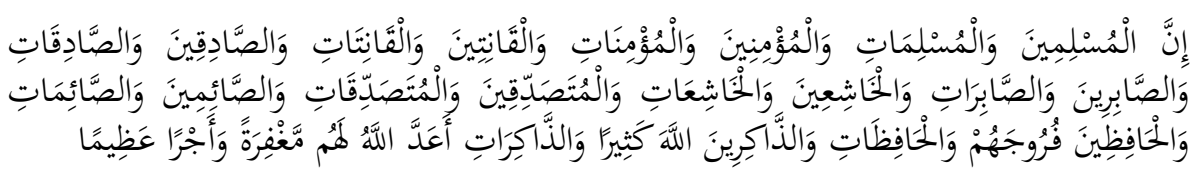

Muslimanima i muslimankama, i vjernicima i vjernicama, i poslušnim muškarcima $i$ poslušnim ženama, $i$ iskrenim muškarcima $i$ iskrenim ženama, $i$ strpljivim muškarcima $i$ strpljivim ženama, $i$ poniznim muškarcima i poniznim ženama, i muškarcima koji dijele zekat $i$ ženama koje dijele zekat, $i$ muškarcima koji poste $i$ ženama koje poste, $i$ muškarcima koji o svojim stidnim mjestima vode brigu i ženama koje o svojim stidnim mjestima vode brigu, i muškarcima koji često spominju Allaha i ženama koje često spominju Allaha - Allah je, doista, za sve njih oprost $i$ veliku nagradu pripremio. (Kur'an, El-Ahzab, 35.)

Međutim, kako su muškarac i žena po svom spolu drugačiji tako im je Uzvišeni Bog dodijelio, sukladno tome, uloge $u$ životu da se međusobno nadopunjuju $\mathrm{i}$ da se uzajamno ispunjavaju $\mathrm{i}$ ostvaruju $\mathrm{u}$ ovom životu. To je mudrost savršenog Kreatora kako to i Kur'an opisuje:

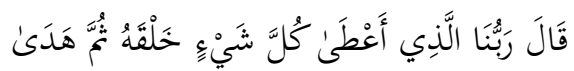

Gospodar naš je Onaj koji je svemu onom što je stvorio dao ono što mu je potrebno, zatim ga, kako da se time koristi, nadahnuo. (Kur'an, TaHa, 50.)

Žene i muškarci su stvoreni kao dva spola sa specifičnim mogućnostima i funkcijama i zbog toga $u$ islamu imaju i specifične uloge za koje su svako od njih fizički, psihički i emocionalno dizajnirani i predodređeni od mudrog Kreatora. Tako samo žena može rađati, i samo ona ima majčinsku, jedinstvenu vezu sa svojim djetetom, što je predodređuje i čini više odgovornom za njegovu brigu i odgoj te smješta njenu prirodnu i normalnu sferu aktivnosti u topli kućni milje koji pogoduje podizanju djece. Muškarac po fizičkim preddispozicijama je jači od žene, i data mu je odgovornost kompatibilna sa tom prirodom, da zarađuje, brine i skrbi za izdržavanje porodice tako da je njegova prirodna sfera aktivnosti u društvu i više izvan kuće. Ovo je prirodna 
podjela sfere djelovanja muškarca i žene, što nikako ne znači da za ženu nije neki drugi posao izvan kuće ili da muškarac ne treba da brine za kućne poslove. Međutim, to je praksa koja je najbolje funkcionirala $\mathrm{u}$ historijskom hodu čovječanstva. Načelo podjele po prirodi stvari za koju je neko sposobniji, ne treba narušavati, jer se onda od reda pravi nered, i umjesto efikasnog funckioniranja i reda, dobije nered i propadanje. Naglasivši ulogu žene, njenu prirodu i sposobnost $u$ porodici islam je udaljava od svega što ne odgovara njenoj prirodi, propisuje joj propise koji se odnose samo na nju, tako da je žena oslobođena određenih vjerskih $i$ društvenih obaveza, kao što su: džematski, kolektivni namazi, džuma, obavezno nošenje posebne odjeće ihrama na hadždžu, obaveze ratovanja, osim u vremenu opće mobilizacije i sl. Naravno, sve ovo ne dovodi u pitanje njeno načelo jednakosti sa muškarcem u vezi s pitanjem ljudskosti, sposobnosti ili društvenog položaja.

Oslobađanje žene od prokletstva iskonskog grijeha

Islamska doktrina ne optužuje nikoga za tuđi grijeh. Uzvišeni to proklamuje u Kur'anu na više mjesta u različitim kontekstima, ali uvijek po principu samo lične odgovornosti:

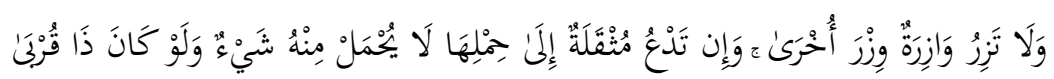

I nijedan grješnik neće grijehove drugog nositi; ako grijehovima pretovarenī pozove da mu se ponesu, niko mu ih neće ponijeti, pa ni rođak... (Kur'an, Fatir, 18.)

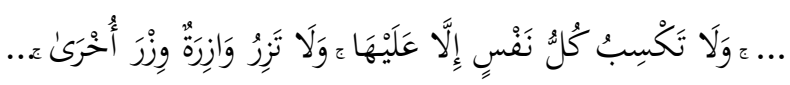

Što god ko uradi, sebi uradi, i svaki grješnik će samo svoje breme nositi. (Kur'an, El-En'am, 164.)

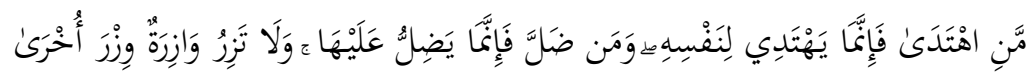

Onaj ko ide Pravim putem, od toga će samo on koristi imati, a onaj ko luta - na svoju štetu luta, i nijedan grješnik neće tuđe grijehe nositi. (Kur'an, El-Isra', 15.)

Stoga, islam oslobađa ženu i njenu pramajku prokletstva nametnutog $\mathrm{u}$ iskrivljenim ideologijama i doktrinama ranijih vjera, u pravnim običajima i tradicijama, tako što izgnanstvo prvog čovjeka iz raja/dženneta ne tretira kao isključivo njenu krivicu, nego je formuliše 
kao zajedničku krivicu prvog ljudskog para Adema i Have, a koja se u ajetu raspodjeljuje zajedno na oba praroditelja čovječanstva. I da u tome ne bude nikakve zabune počinioci tog grijeha spominju se u ajetu eksplicitno u dvojini:

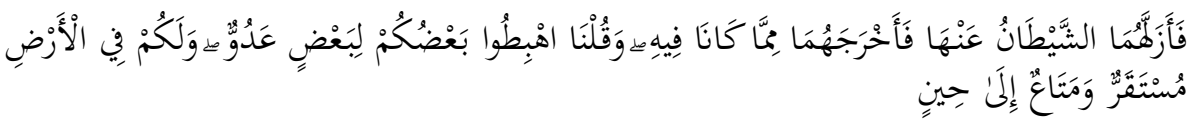

I šejtan ih navede da zbog drveta posrnu i izvede ih iz onoga u čemu su bili. "Sidite!" - rekosmo Mi - "jedni drugima ćete neprijatelji biti, a na Zemlji ćete boraviti i do roka određenoga živjeti!" (Kur'an, El-Bekare, 36.)

Šejtan je bajao i zavodio oboje, kako Kur'an navodi:

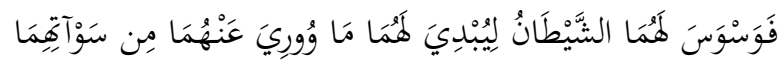

I šejtan im poče bajati da bi im otkrio stidna mjesta njihova, koja su im skrivena bila. (Kur'an, El-E'araf, 20.)

U Kur'anu se dalje govori o njihovom zajedničkom grijehu kroz izraze dvojine u Kur'anskom kazivanju, a ajet čak završava sa konstatacijom da je Adem, a.s., pogriješio, ne spominjući dalje grijeh pramajke čovječanstva.

Uzvišeni kazuje:

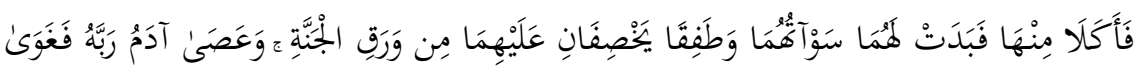

I njih dvoje pojedoše s njega i ukazaše im se stidna mjesta njihova pa počeše po njima lišće džennetsko stavljati - tako Adem nije Gospodara svoga poslušao i s Puta je skrenuo. (Kur'an, Ta-Ha, 121.)

Međutim, bilo ko od njih dvoje da je samostalno pogriješio, taj iskonski grijeh se u islamu ne nasljeđuje, niti se zbog njihove pogreške pripisuje odgovornost, nasljedno, njihovom zajedničkom, ljudskom rodu, jer Uzvišeni kaže:

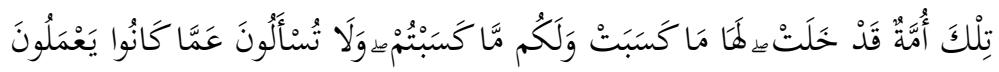

Taj narod je bio i nestao; njega čeka ono što je zaslužio, $i$ vas će čekati ono što ćete zaslužiti, $i$ vi nećete biti pitani za ono što su oni radili. (Kur'an, El-Bekare, 134.) 


\section{Akika - radost i zahvalnost Bogu na daru muškog i ženskog djeteta}

Radost dobijanja djeteta, $\mathrm{u}$ islamu se proslavlja akikom u kojoj se iz zahvalnosti dragom Bogu, po pritvrđenom sunnetu, kolje i prinosi žrtva akike, kurbana. Predaju u tom smislu zabilježio je Ebu Davud (2842.), a Albani je ocijenio u Sahihu Ebu Davuda kao lijepu, kada je Allahov Poslanik, s.a.v.s., kazao:

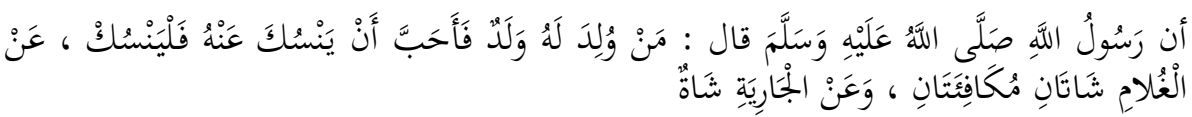

Onome kome se rodi dijete i poželi da postupi propisno u tome, neka kao žrtvu prinese za muško dvije slične ovce, a od ženska ovcu.

Isto tako su zabilježili Tirmizi (1516.) i Nesai (4217.) od Ummu Kurzin, po Albaniju vjerodostojnu predaju ${ }^{2}$, da je ona pitala Allahovog Poslanika, s.a.v.s., o akiki pa je on kazao:

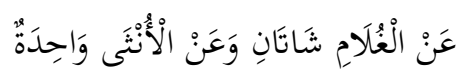

Za muško (prinijeti) dvije, a za žensko jednu ovcu.

Pravni stav po ovom pitanju kod mezhebskih pravnika ${ }^{3}$ je sljedeći:

Prinošenje žrtve kod šafija i hanbelija sa dvije ovce za muško i jedne ovce za žensko kategorije je mustehabba, dok je stav hanefija i malikija da se jedna ovca žrtvuje isto za muško kao i za žensko.

Uz ovo se mora nadodati kako Uzvišeni Allah kritikuje i kudi ružni običaj predislamskih Arapa koji su izražavali tugu i potištenost kod vijesti o rođenju ženskog djeteta. Uzvišeni to prekorijeva:

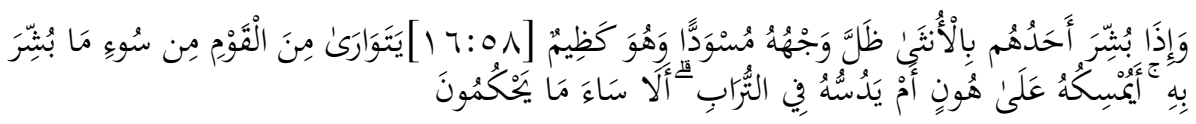

I kad se nekome od njih javi da mu se rodila kći, lice mu potamni $i$ postaje potišten, krije se od ljudi zbog nesreće koja mu je dojavljena; da li ovako prezren da je zadrži ili da je u zemlju zarovi? Kako ružno oni prosuđuju! (Kur'an, El-Nahl, 58-59.)

\footnotetext{
2 Irvaul-galil: 4/391.

${ }^{3}$ El-Mevsu'atul-fikhijje: 30/280.
} 
Izraz Uzvišenog u ovom ajetu je ,iza buššire ehaduhum“, tj. „kada bude obveseljen" viješću da se rodilo žensko dijete, što i jezičkim značenjem upućuje na radost da se našlo i rodilo žensko dijete, a onda kori one čija lica zbog toga potamne i postanu potištena, umjesto da se vesele. Konačno Allahova je volja kome će dodijeliti i pokloniti žensku ili mušku djecu, a koga će ostaviti bez poroda. Uzvišeni kazuje o toj blagodati djece i opet u ajetu prvo spominje žensko dijete. Sve to je vid Kur'anske nadnaravnosti i božanstvenosti koju samo On Uzvišeni, tako usput, kroz Svoje nenadmašne ajete promovira, ukazujući kroz to na vrijednost ženskog djeteta te da se u islamu poštuje žensko kao i muško biće:

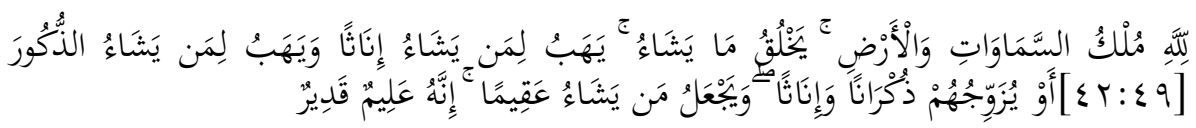

Allahova je vlast na nebesima $i$ na Zemlji. On stvara šta hoće! On poklanja žensku djecu kome hoće, a kome hoće - mušku, ili im daje $i$ mušku $i$ žensku, a koga hoće, učini bez poroda; On uistinu sve zna i sve može. (Kur'an, Eš-Šura, 49-50.)

Suprotno od ovih kur'anskih vrijednosti, predislamski Arapi su smatrali da je rođenje muškog dijeteta blagodat, da je to ponos i snaga porodice/plemena, a da je rađanje ženskog dijeteta poniženje, sramota $i$ nesreća, tako da su u tom svom plemenskom i društvenom džahilijetu imali i ustrojili običaj zakopavanja žive ženske, tek rođene djece. To je islam dokinuo dajući revolucionarna poboljšanja u položaju i statusu žene!

\section{Preporuka i stimulacija brige za žensko: kćerima, suprugama i majkama}

Briga za ženu kćerku, suprugu i majku došla je kroz mnogobrojne Kur'ansko-hadiske tekstove iz kojih se razumiju prava i povlašteni položaj i status žene koji joj daje sistem islama praveći balans između njene ljudske prirode i prava koja ona uživa:

Briga o kćerima

Allahov Poslanik, s.a.v.s., izrekao je mnogobrojne hadise preporuka, stimulacije i brige, prvo za majkama, suprugama a onda i kćerima, koji su došli u vjerodostojnim verzijama, zabilježini od najvjerodostojnijih 
autoriteta hadisa. Muslim bilježi predaju od Enes b. Malika, r.a., da je Allahov Poslanik, s.a.v.s., rekao:

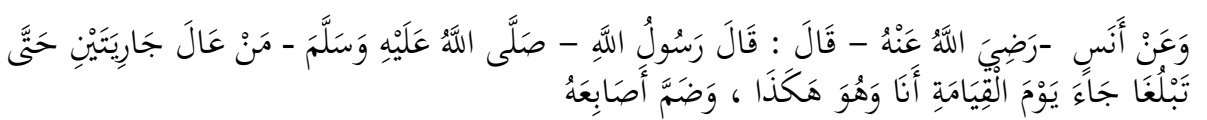

Kazao je Allahov Poslanik, s.a.v.s.: - Ko se bude brinuo i izdržavao dvije kćeri do njihovog punoljetstva, doći će na Sudnjem danu zajedno sa mnom. Skupio je prste pokazujući kako će njih dvojica biti zajedno kao dva prsta.

Ibni Madže je zabilježio vjerodostojnu predaju, po Albaniju, od Enesa, r.a., koji prenosi da je Vjerovjesnik, s.a.v.s., kazao:

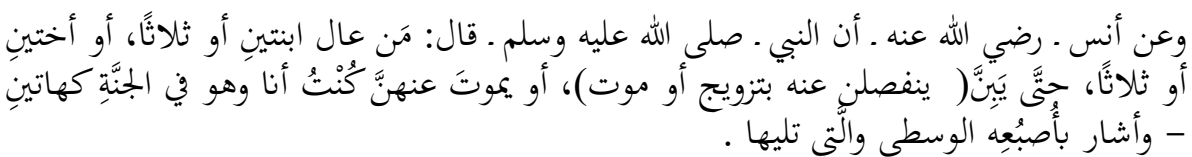

Ko se bude brinuo i izdržavao dvije ili tri kćeri, ili dvije ili tri sestre do momenta kada se razdvoje od njega, udajom ili smrću, ili on umre a one ostanu, biće zajedno sa mnom u džennetu kao što su ova dva prsta zajedno. Zatim je pokazao srednji i prst do njega.

Ahmed je zabilježio predaju, koju Albani drži vjerodostojnom, od Džabira b. Abdullaha, r.a., da je Vjerovjesnik, s.a.v.s., kazao:

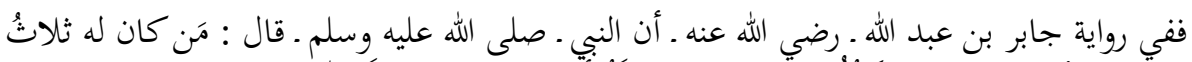

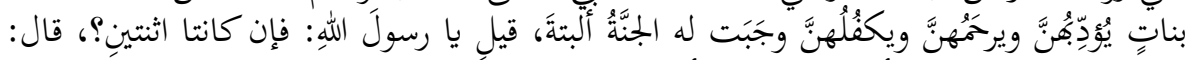

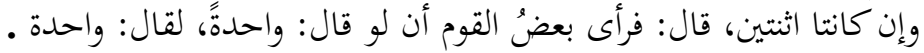

- Ko bude imao tri kćeri pa ih odgoji, bude im pažljiv i pobrine se za njihovo izdržavanje, sigurno mu je zagarantovan džennet. Upitaše ga: - Allahov Poslaniče, a ako bude imao dvije? On kaza: - I ako bude imao dvije. Neki smatraju da je kojim slučajem bilo postavljeno pitanje i o samo jednoj kćeri, odgovorio bi bio pozitivan.

O odnosu oca prema kćerki i njenom poštivanju, i obratno, najbolje nam govori primjer Poslanika, s.a.v.s., u kojem A'iša, r.a., opisujući sličnost sa Allahovim Poslanikom, s.a.v.s., u tom postupku, navodi da nikoga nije vidjela sličnijeg Poslaniku, a.s., u takvom ophođenju do kćerke mu Fatime. Aiša kazuje, kako je zabilježio Ebu Davud u svome Sunenu (5217), a Albani ocijenio kao vjerodostojnu predaju (Sahihut-Tirmizi: 4146.): 


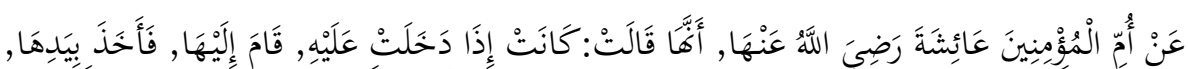

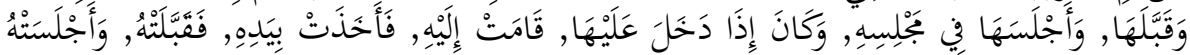

... Kada bi Fatima ušla kod Poslanika, ustao bi i poljubio je, te je posadio pored sebe. A kada bi Poslanik ušao kod nje, ustala bi, poljubila ga i napravila mu mjesto pored sebe.

\section{Briga o suprugama}

Što se tiče poštivanja žene kao supruge o tome govore mnogobrojni ajeti, a Uzvišeni kaže u suri er-Rum:

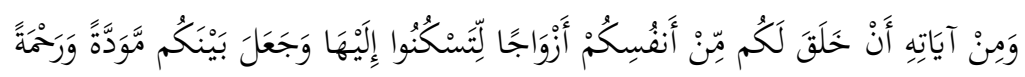

i jedan od dokaza Njegovih je to što za vas, od vrste vaše, stvara žene da se uz njih smirite, $i$ što između vas uspostavlja ljubav i samilost; (Kur'an, Er-Rum, 21.)

U suri en-Nisa' kaže:

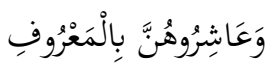

S njima lijepo živite! (Kur’an, En-Nisa', 19.)

O islamu su izrečene mnogobrojne laži i neistine. Posebno se šire neistine o islamskoj doktrini u pogledu na ženu i njen položaj u islamu. Međutim, istina je da je položaj žene u islamu izuzetno povoljan i povlašten. Pojavom islama revlucionarno je poboljšan status žene $u$ historiji čovječanstva. Neke intelektualke iz Njemačke, u svom proučavanju istinskih, realnih vrijednosti položaja žene u islamu i komparirajući to sa lažnom emancipacijom žene na zapadu primile su islam želeći da se okoriste tim povlaštenim položajem žene u islamu.

Da se razumije kako islam doktrinarno gleda na ženu dovoljno je citirati par citata hadisa Poslanika, a.s., o ženi i vijednosti žene:

Muslim (1467.) bilježi od Amra b. El-A'sa da je Poslanik, a.s, rekao:

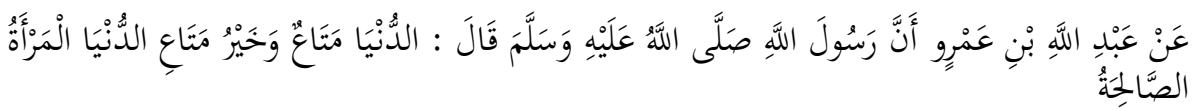

Dunjaluk je uživanje i naslada a njegova najveća vrijednost je poštena žena.

A Ibni Madže (1855.) zabilježio je ovaj hadis kao sljedeću predaju: 


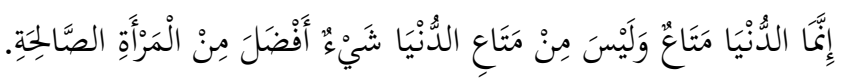

Dunjaluk je uživanje i naslada, nema veće ovosvjetske vrijednosti nego što je poštena žena.

Ebu Davud bilježi od Ibni Abbasa da je Poslanik, a.s, rekao:

Hoćete li da vas obavijestim o blagu koje se čuva. Poštena žena koju čovjek kada pogleda obraduje ga, kada je ostavi čuva mu čast i obraz, i kada joj naredi pokori mu se.

Tirmizija i Ibni Madždže bilježe da su ashabi na jednom putovanju, nakon što je objavljen ajet koji govori o zabrani gomilanja zlata i srebra, a da se ne daje zekjat, rekli:

...Da nam je znati koji imetak i koja vrijednost je najvrednija pa da to štedimo i gomilamo?" Poslanik, a.s., rekao je: ,,To je jezik koji zikrom zbori, srce koje je zahvalno $i$ žena vjernica koja je oslonac u vjerovanju."

Eto, tako islam vrjednuje ženu kao najveće dunjalučko blago i u tom smislu, to je bio revolucionarni napredak tretmana žene u dotašnjim svjetskim, vladajućim, pravnim običajima. Dakle, islam oslobađa ženu i revolucionarno mijenja njen položaj i status na bolje, jer je u džahilijetskom-predislamskom vremenu i društvu njen položaj bio nedostojan, ropski i ona je kao član zajednice i društva bila obespravljena.

Allahov Poslanik Muhammed, s.a.v.s., čak ni na oprosnom hadžu na Arefatu, u hutbi oprosnog hadždža kada je ummetu ostavljao zadnju oporuku, govoreći o najvažnijim temama islamskog sistema življenja, nije zaboravio spomenuti prava žena. Tirmizi je zabilježio od Sulejmana b. A'mra el-Ahvesa koji pripovijeda od svoga oca:

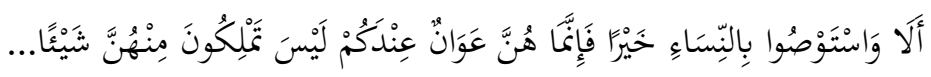

Oporučujem vam da ženama činite dobro, da prema njima lijepo postupate. One su kod vas kao robinje, iako vi od njih ne posjedujete ništa...

Buharija $^{4}$ i Muslim su zabilježili predaju od Ebu Hurejre, r.a.:

${ }^{4}$ Sahihul-Buhari, kitabun-nikah, babul-Vesati bin-nisai 


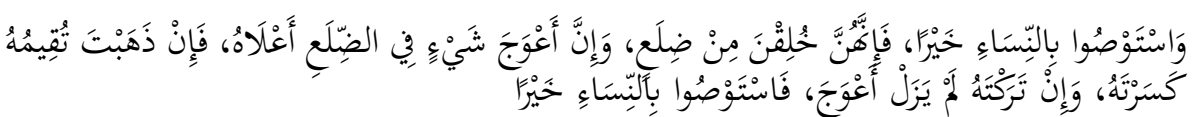

Oporučujem vam da ženama činite dobro! Zaista je žena stvorena od rebra, a najveća krivina rebra je baš njegov najviši dio, pa ako ga pokušaš ispraviti, slomit ćeš ga, a ako ga ostaviš, osta krivo. Zato jedni drugima preporučujte da ženama dobro činite!

Čak i u smrtnoj bolesti, u zadnjem obraćanju ashabima kada su ga bolesnog unijeli u džamiju Allahovog Poslanika u Medini, prenosi se da je Allahov Poslanik opetovano kazao ashabima i izrekao oporuku da se žene paze, paze, paze

$$
\text { تم قال : أيها الناس، اتقوا الله في النساء، اتقوا الله في النساء، اوصيكم بالنساء خيرا }
$$

Bojte se Allaha u pogledu žena! Bojte se Allaha u pogledu žena! Činite ženama dobro!

Poštivanje majke

A o poštivanju žene kao majke, dakle, jednog od roditelja, Uzvišeni kaže zadužujući svakog čovjeka sa dobročinstvom prema njima:

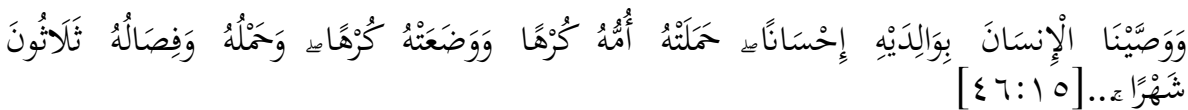

Čovjeka smo zadužili da roditeljima svojim čini dobro; majka njegova s mukom ga nosi i u mukama ga rađa, nosi ga i doji trideset mjeseci... (46:15.)

U ajetu kojim se naređuje obožavanje jedino Uzvišenog Allaha, uporedo sa tom najvišom kategorijom ibadeta bez kojeg ne vrijede sva druga ljudska dobročinstva i ibadeti, Uzvišeni naređuje i dobročinstvo prema roditeljima, majci i ocu:

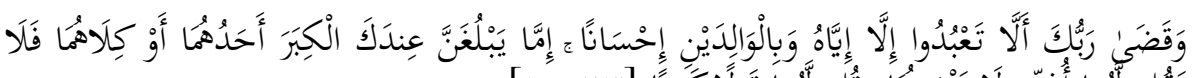

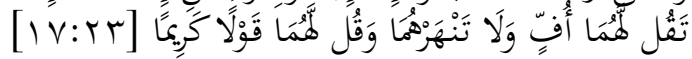

Gospodar tvoj zapovijeda da se samo Njemu klanjate $i$ da roditeljima dobročinstvo činite. Kad jedno od njih dvoje, ili oboje, kod tebe starost

${ }^{5}$ https://ar-ar.facebook.com/Astawso.Belnesaa2.../51286493214464...pristupljeno 10, novembar, 2017. 
dožive, ne reci im ni: "Uh!" - i ne podvikni na njih, i obraćaj im se riječima poštovanja punim. (17:23.)

Buharija (5626.) zabilježio je od Ebu Hurejre, r.a., koji kazuje:

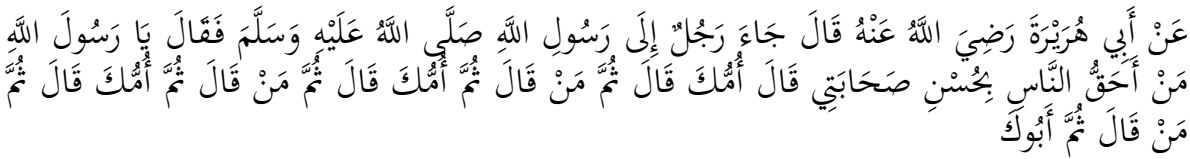

Došao je čovjek Allahovom Poslaniku pitajući ga: -Allahov Poslaniče, ko je najpreči mom lijepom postupanju i ponašanju prema njemu? Allahov Poslanik kaza: - Tvoja majka. On ponovo upita: - A ko poslije nje? Allahov Poslanik kaza: -Tvoja majka. - A ko poslije nje? - ponovo upita. Allahov Poslanik kaza: - Tvoja majka. - A ko poslije nje? ponovo upita. Allahov Poslanik, s.a.v.s., onda kaza: - Zatim tvoj otac.

Poslovna sposobnost, pravo vlasništva, nasljeđivanja i mehra

Pojavom islama dokidaju se običajni, izrabljivački i nepravedni odnosi, pravni običaji diskriminacije žene u predislamskom društvu, a ženama se daje pravo vlasništva. I ne samo to, nego islam ide i dalje pa daje ženi obavezno, diskreciono pravo vjenčanog dara (mehr), kao nagradu ili vid materijalne sigurnosti ulaska u brak, kao i pravo nasljeđivanja, što govori o visokoj vrijednosti božanskog sistema Šerijata.

Neprijatelji islama napadaju i sa aspekta diskriminacije žene i njene imovinske ne/ravnopravnosti, što je potpuni promašaj, zla namjera i neprijateljstvo bezpokrića, jer žena ostvaruje diskreciona imovinska prava koja ne ostvaruje muškarac, kao što je vjenčani dar (mehr), ima potpunu poslovnu sposobnosti potpuno slobodno raspolaže svojom imovinom po svim osnovama, sa mehrom, nasljedstvom, zaradom, darovima, a i ako je imućna, uopće nije dužna iz svoje imovine izdržavati, hraniti i odijevati muža i djecu, nego je to obaveza muškarca/supruga. Istina, nasljedni dio kćerke i sina nije isti, međutim, sinu je potrebno više imetka jer muškarac ulaskom u brak obezbjeđuje mehr za svoju ženidbu, obavezan je da skrbi, izdržava i troši na svoju porodicu, dok žensko/kćerka nije dužna trošiti na izdržavanje porodice. Ustvari, islam ne samo da je nije diskriminirao i oštetio, nego ju je oplemenio i na poseban stepen uzdigao, tako što je ona kao kćerka, supruga, majka zbrinuta od rođenja pa do smrti, jer do udaje o njoj brine muško/otac, a poslije udaje isto tako muško/suprug. Dakle, muškarcu 
je povjerena skrb i briga za porodicu, što ni u kom slučaju, ne podrazumijeva potčinjavanje ili nepravdu za ženu, nego upravo suprotno, to govori o povlaštenosti žene u islamu, i obavezi i teretu koji se stavlja na pleća muškarca.

U islamskom nasljednom pravu (mevaris) žensko kao majka, supruga ili kćerka, svejedno, bila odrasla ili malodobna osoba, pa čak i ako je postojala kao beba u majčinoj utrobi imas i dio nasljedstv a u savršenim odredbama božanskog, kur'anskog prava zasnovanog na principu pravde koji joj je odredio Svevišnji, eksplicitno, ne ostavljajući da to određuje bilo ko drugi; da dijeli zaostavštinu po svom nahođenju, da njome eventualno manipulira, pa čak ni Poslanik islama, već ju je Uzvišeni do detalje razradio i ponudio u Kur'anu, kao rijetko pitanje koje je riješeno njegovim božanskim normama. Zbog toga, u historiji čovječanstva ne postoji, niti je postojao sistem nasljeđivanja koji se po svojoj pravednosti i sistemu zaštite prava svih nasljednika, može takmičiti sa islamskim nasljednim pravom.

Posebno je poznat status žene u ranijim ljudskim sistemima i njena diskriminacija u podjeli zaostavštine, pa čak i čitav milenij nakon što je islam počastio ženu sa božanskim, pravednim sistemom nasljeđivanja.Te vrijednosti koje islam daje ženi nisu poznavali mnogi pravni sistemi ni hiljadu godina poslije pojave islama. Prije pojave islama pravo vlasništva žene bilo je narušeno pravom skrbnikastaratelja koji je mogao slobodno raspolagati sa čitavim njezinim imetkom. Mnogi ne znaju da je žena i u našim krajevima bila obespravljena hiljadu godina nakon što ju je islam oslobodio i dao joj prava koja zaslužuje.

Dakle, tek dolaskom islama u naše krajeve u Bosni i Hercegovini, šerijatsko zakonodavstvo utiče da se obespravljena žena izjednači sa muškarcem u pravu nasljeđivanja za koje je ona bila prikraćena običajnim pravom, a posebno u domenu nasljeđivanja nekretnina.

Dr. Vojislav Spaić raspravlja o utjecaju šerijatskog prava na nasljednopravne običaje u Bosni i Hercegovini u svojoj doktorskoj disertaciji pod naslovom Nasledno običajno pravo $u$ BiH, koja je odbranjena 22. marta 1941. godine na Pravnom fakultetu u Beogradu.

A profesor je, 1967. godine, objavio vrijednu naučnu studiju pod naslovom Nasljednopravni običaji u BiH nakon Austro-Ugarske 
okupacije, u zbirci Radovi Akademije nauka i umjetnosti Bosne i Hercegovine. $^{6}$

U ovoj studiji, prof. Spaić je objavio integralni tekst Projekta nasljednog zakona, koji je urađen prije Drugog svjetskog rata, ali nikad nije ozakonjen.

On navodi u svojoj studiji o nasljeđivanju žena: “... pa se, s potpunim pravom, može reći da su žene bile isključene iz nasljeđivanja nekretnina. Osim toga, ne smijemo zaboraviti da su ovi pravni običaji koji dozvoljavaju ženama nasljedstvo vlastite zemlje nastali pod utjecajem turskog zakonodavstva."7

Prema tome, šerijatski zakon priznaje prava žene hiljadu godina prije nego je to pravo, i to tek uticajem islama i njegovog šerijatskog zakona, žena dobila u našim krajevima.

Bračni ugovor

Islam je posvetio posebnu pažnju bračnom sporazumu i ugovoru dajući mu i posebnu ulogu, između ostalih ugovora koji se sklapaju, zbog svih pravnih posljedica koje prouzrokuje, ne samo kod onih koji su neposredni sudionici ugovora - suprug i supruga - nego i kod njihovih porodica i čitavog društva. Taj ugovor daje i gradi posebne, nove tazbinske odnose koji se utemeljuju brakom i imaju mnogobrojne, specifične, pravne posljedice u društvu.

\section{Razvod}

U šerijatu je regulisano i pitanje razvoda braka čime je spriječena samovolja muškarca kojem je postavljena granica u vidu tri talaka, ili samo tri mogućnosti prava na razvod. Prije islama nije bilo ograničavanja broja, niti vremenskog trajanja perioda razvoda braka. Iddet ili period postrazvodnog pričeka dao je odgođenu mogućnost supružnicima da dobro promisle, izvažu sve koristi i štete od razvoda, a onda da se ponovo vrate zajedničkom životu, ako takva ideja prevagne kod njih.

${ }^{6}$ Vojislav Spaić, Nasljednopravni običaji u BiH nakon Austro-Ugarske okupacije, Akademija nauka i umjetnosti BiH, knjiga XXXII., Odjeljenje društvenih nauka, knjiga 11., Sarajevo, 1967.

${ }^{7}$ Ibid., 64. Vidi, također, o utjecaju turskog zakonodavstva, str. 61. 
U džahilijetskom, predislamskom dobu bilo je nazamislivo da žena ima pravo da traži razvod braka od muža, međutim, šerijat joj je dao i tu mogućnost, ali za koju se trebaju ispuniti određeni uslovi da bi se praktično realizovala. Ovo upućuje na to da je islam dao mnoga nova prava ženi, ponudio joj ulogu na ovom svijetu koja joj i pripada, i uzdigao ju je kao humano ljudsko biće iz predislamskog mračnjaštva $i$ nepravde koju je historijski preživljavala na stepen ravnopravnog člana društva.

\section{Ograničavanje višeženstva na samo četiri žene}

Kod Arapa koji su prakticirali višeženstvo i bili direktni objekat zadnje Božije Poslanice, kao što je bio slučaj i kod nekih drugih predislamskih naroda, praksa poligamije nije bila ograničavana važećim pravnim običajima. Dolaskom islama, Uzvišeni je, ograničio poligamiju na najviše četiri žene, $\mathrm{u}$ isto vrijeme, $\mathrm{i}$ to pod uvjetom da se bude pravedno prema ženama, inače je dozvoljeno imati samo jednu ženu. Uzvišeni kaže:

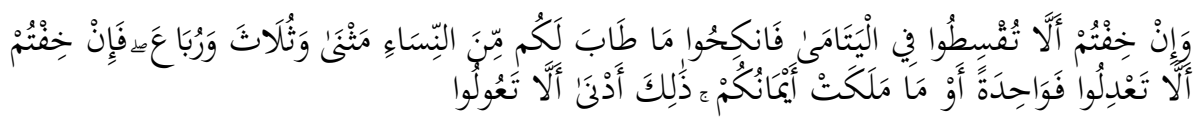

Ako se bojite da prema ženama sirotama nećete biti pravedni, onda se ženite onim ženama koje su vam dopuštene, sa po dvije, sa po tri i sa po četiri. A ako strahujete da nećete pravedni biti, onda samo sa jednom; ili - eto vam onih koje posjedujete. Tako ćete se najlakše nepravde sačuvati. (Kur'an, En-Nisa', 3.)

Što se tiče poligamije u islamu, to je pitanje zbog kojeg kritičari islama prigovaraju šerijatskom sistemu kao sistemu koji diskriminira ženu. Oni navode upravo primjer poligamije zamišljajući tu praksu kao inovaciju islamskog šerijatskog prava koja prouzrokuje mnogobrojne društvene i porodične probleme i štete.

Međutim, uopće ne uzimaju u obzir činjenicu da islam nije inovirao pogamiju, niti ju je naredio. To je praksa koju su poznavali prijašnji narodi, ranije nebeske vjere i stare, drevne civilazacije.

Poznato je da je u Perzijskoj civilizaciji bila praksa poligamije, družica i mnogobrojnih robinja, zbog stalnih ratova koji su bili u potrebi za novim mladim borcima. 
Isto je bio slučaj i sa starom Bizantijom i njenim imperatorima, sa starim Grcima koji nisu ograničavali poligamiju, kao ni stari Egipćani, Hindusi, Asirci i drugi.

U židovskim izvorima, Tevratu i Talmudu, dozvoljava se neograničena poligamija, a za Božijeg poslanika, Sulejmana (Solomona), tvrdi se da je imao 700 žena i 300 robinja.

Pošto je Tevrat izvor i za kršćanstvo, onda se to odnosi i na kršćanstvo u kojem se navode i Isusove riječi da je došao, ne da derogira i kritikuje prijašnje sisteme i poslanike, nego samo kako bi upotpunio prijašnje. Prema tome, poligamija je ostala u kršćanskim zemljama sve do 16 stoljeća kada će, tek, Crkva ograničiti poligamiju i prikloniti se monogamiji, kao što je to ranije učinilo i judejstvo kada je rabin Geršom bin Jehudah (960-1030) objaviti poseban akt protiv višeženstva ${ }^{8}$.

\section{Dr. Zakir Naik tvrdi:}

„Kur'an je jedina religiozna knjiga, na ovoj zemlji, koja sadrži frazu 'oženi samo jednu'. Nema druge vjerske knjige koja naređuje/upućuje čovjeka da ima samo jednu ženu. U svim drugim religijskim skriptama, bilo to u Vedi, Ramayani, Mahabharati, Geeti, Tori ili Bibliji, ne može se naći restrikcija u ženidbi više žena. Prema ovim knjigama jedan čovjek može oženiti koliko želi žena. Tek je kasnije, uspostavljeno od strane hinduskih sveštenika i hrišćanske crkve da svedu broj žena na jednu. Mnoge su ličnosti iz hinduskih vjerskih spisa imale više od jedne žene. Kralj Dašrat, otac Rama, imao je više od jedne žene. Krišna je imao nekoliko žena."9

Islam je donio nekoliko propisa sa kojima je zaštitio društvo i članove tog društva: ograničio je broj žena u jednom braku, uvjetovao je mužu da bude pravedan prema svim ženama jednako, inače se mora vratiti na monogamiju, i dao je pravo prvoj ženi da može sklopiti brak s uvjetom prava razvoda, ukoliko muž želi da pored nje ženi drugu ženu. Putem ovih ograničavajucih propisa, islam je zaštitio sve interese društva i njegovih članova: muža, ženu i djecu. Svi ovi članovi mogu da žive u okvirima zakonskih propisa, $i$ da budu poštovani od drugih, jer

\footnotetext{
${ }^{8}$ www.novihorizonti.ba/poligamija-visezenstvo/, pristupljeno, 18. novembra 2017.

${ }^{9}$ https://id.scribd.com/document/.../Dr-Zakir-Naik-Poligamija-u-Isla..., posjećeno, 18. novembra, 2017.
} 
su unutar pravne regulative. Suprotno od ove situacije, oni koji kritički gledaju na šerijatske propise, a u isto vrijeme dozvoljavaju i tolerišu sve vrste razvrata, nebračnih odnosa licemjerno govoreći samo o monogamiji kao jedinom rješenju; oni su izgubili svako poštovanje, prelaze granice dobrog ukusa $i$ preferiraju anarhiju nad redom $i$ razvijenim sistemom.

Briga i skrb za maloljetnice koje nemaju roditelje

Ashabi su bivali tutori maloljetnim ženskim sirotama-jetimimima, lijepo postupajući prema njima, čuvajući, pazeći i razvijajući njihov imetak. U njihovom vremenu desio se slučaj da se jedan ashab oženio sa siroticom za koju se brinuo i skrbio. Međutim, nije joj dao mehr, kao njeno diskreciono pravo, vjenčani dar koji pristoji njenom statusu, misleći da je dovoljno to što se za nju brinuo i skrbio te da to tutorstvo može zamijeniti i igrati ulogu vjenčanog dara. Međutim, Uzvišeni je i to zabranio ajetom $u$ suri en-Nisa:

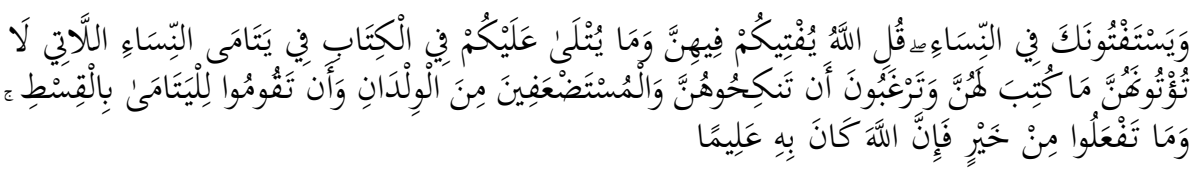

Oni traže od tebe propise o ženama. Reci: "Allah će vam objasniti propise o njima - nešto vam je već kazano u Knjizi o ženama sirotama, kojima uskraćujete ono što im je propisano a ne želite se njima oženiti, i o nejakoj djeci, i o tome da sa siročadi trebate pravedno postupati. A Allah, sigurno, zna za dobro koje učinite. (Kur'an, En-Nisa', 127.)

Dakle, iako je u ajetu pitanje o propisima žena općenito, odgovor je u istom ajetu o najranjivijoj njihovoj kategoriji, za koju Uzvišeni posebno brine, a to su sirote koje su pod skrbništvom.

Aiša, r.a., majka vjernika, komentariše spomenuti ajet i kaže u predaji koju je zabilježio Buhari (4574):

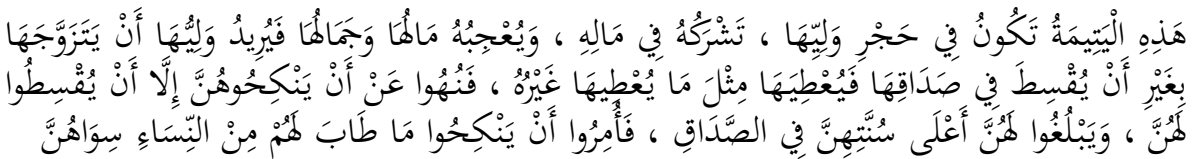

Ovo se odnosi na sirotu koja je pod tutorstvom skrbnika, a ima pravo $u$ njegovom imetku, pa mu se svidi ona i njen imetak, tako da je zbog toga hoće oženiti, ali bez da joj da odgovarajući vjenčani dar (mehr) koji bi joj, inače, dao drugi. Takvim starateljima je zabranjeno da vjenčavaju 
sirote za koje skrbe, osim ako će im dati mehr kao i neki drugi prosac, kako bi dobile najviše što je sunnetom propisano, inače im se naređuje (tutorima) da žene druge žene, osim tih sirota.

Uzvišeni Allah, kazao je i sljedeće:

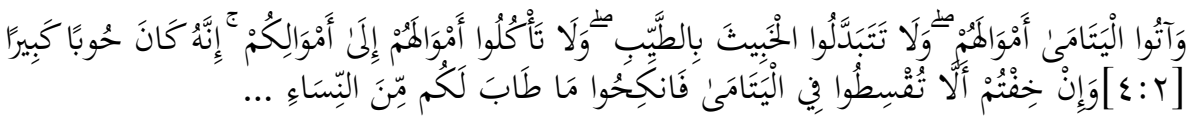

I siročadi imanja njihova uručite, hrđavo za dobro ne podmećite $i$ imetke njihove s imecima vašim ne trošite - to bi, zaista, bio vrlo veliki grijeh. Ako se bojite da prema ženama sirotama nećete biti pravedni, onda se ženite onim ženama koje su vam dopuštene... (Kur'an, En-Nisa', 2-3.)

Prema tome, značenje ajeta otkriva Aiša, r.a., kada objašnjava da se dešavalo da neko bude skrbnik sirotici. Ako je lijepa, oženi je, bez plaćanja odgovarajućeg mehra. A ako nije poželjna, onda ženi neku drugu. Zbog toga je došla zabrana da ih njihovi staratelji žene osim ako će im pravedni biti i ako će im platiti najvišu cijenu mehra koju bi im platio neko drugi, inače neka žene druge žene. Ovim se promovira briga za sirotu, njen imetak, podrazumijeva zaštita, odgoj, briga i unapređenje njenog imetka. Prema tome, ova vrsta strateljstva u islamu nije nipošto značila posjedovanje i porobljavanje, nego brigu i skrb.

Dakle, staratelj je dužan čuvati imetak jetima-sirota, raditi na njegovom uvećavanju, te im ga predati navršavanjem njihovog punoljetstva, što treba biti u prisustvu svjedoka, kao što Uzvišeni Allah, kaže:

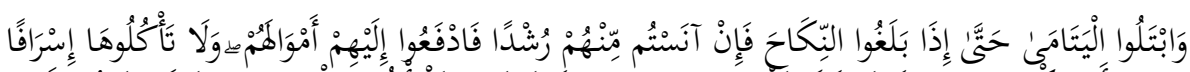

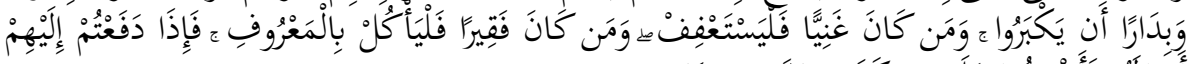

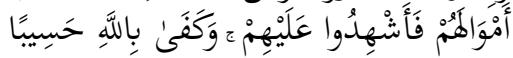

I provjeravajte siročad dok ne stasaju za brak; pa ako ocijenite da su zreli, uručite im imetke njihove. I ne žurite da ih rasipnički potrošite dok oni ne odrastu. Ko je imućan - neka se uzdrži, a ko je siromašanneka onoliko koliko mu je, prema običaju, neophodno troši. A imetke im uručujte u prisustvu svjedoka. A dosta je to što će se pred Allahom račun polagati. (Kur'an, En-Nisa', 6.)

Kao što se vidi iz ajeta, Uzvišeni Allah, naređuje starateljima da $u$ prisustvu svjedoka predaju imovinu siročadima, onda kada se uvjere da su postali punoljetni i kako ne bi došlo do nijekanja preuzetog dijela. S 
punoljetstvom žena stiče sva prava materijalnog raspolaganja i dobija potpunu poslovnu sposobnost, isto kao i muškarac.

\section{Preveniranje mobinga}

Usavremeno doba globalizacije i demokratskih pokreta i procesa ne iznenađuje činjenica kada sredstva informisanja ${ }^{10}$ donose informacije o nekim novim zakonskim rješenjima koja uvode neke zemlje kao što su Njemačka i Italija s kojima se hoće rješiti novi, savremeni i aktualni pravni problemi. Jedno od tretiranih pitanja savremenog zakonodavstva je pitanje mobinga i seksualnog iskorištavanja. Savremena društva su se našla u situaciji da tragaju za rješenjima kako suzbiti seksualno uznemiravanje žena i mobing, posebno u radnom okruženju. Prosto frapira činjenica da ta zakonska rješenja, do kojih se došlo u ovo savremeno doba, kao da su prepisana iz normi Kur'ana, ali su uzeta jednostrano bez nekih drugih, nužnih, moralnih normi koje ih čine efikasnim u praksi. Dakle, zakonodavstvo najvećih ekonomskih zapadnih sila, kaska za Kur'anskim rješenjima preko 1400 godina.

Zašto ova zakonodavstva kasne i kaskaju za šerijatskim?

Iz razloga što se ovi propisi odnose samo na radno okruženje i zaštitu žena, kao ,slabijeg spola" na poslu.

U Italiji su izglasali zakon koji je kopija Njemačkog a u kojem je usvojeno da:

Novi zakonski normativ po kojem žene imaju pravo tužiti i tražiti visoke odštete za duži pogled kolege u njenom smjeru.

Novi zakonski dekret je jedna vrsta prevencije od seksualnog uznemiravanja na radnom mjestu.

... predviđene su najteže kazne za fizičke dodire...Svaki fizički dodir pa čak i rukovanje...

Dakle, radi se samo o jednostranom rješenju i pokušaju zaštite samo ženske populacije i samo u radnom okruženju gdje su one najznezaštićenije.

${ }^{10}$ Dnevni Avaz 28. februara 2008. 
Nadalje, ova zakonodavstva ne propisuju pokrivanje kao sredstvo koje može pridonijeti zaštiti, nego dozvoljavju otkrivanje i pokazivanje djelova tjela, što je eksplicitni ,poziv" na mobing i uznemiravanje.

A Kur'anske norme su univerzalne i ne ograničavaju se samo na poslovno okruženje, nego obuhvataju društvo u svim njegovim sferama i djelatnostima, i ne samo da se odnose na zaštitu ženske nego i muške populacije, kao što se razumije iz spomenutih Kur'anskih normi, pa čak rješavaju odnose roditelja i njihove djece unutar njihovih porodičnih prebivališta.

U Kur'anu se kaže:

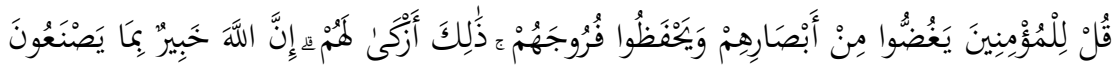

Reci vjernicima neka obore poglede svoje i neka čuvaju stidna mjesta svoja; to im je najčednije, jer Allah, uistinu, zna ono što oni rade. (Kur'an, En-Nur, 30.)

Ebu Davud prenosi od Burejde da je Allahov Poslanik, s.a.v.s., rekao Aliji /314/:

"Ne bacaj pogled za pogledom, imaš pravo na prvi, ali ne i na drugi." Isto se tako naređuje i vjernicama:

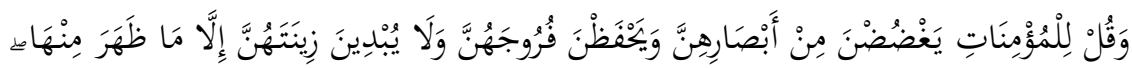

A reci vjernicama neka obore poglede svoje i neka čuvaju stidna mjesta svoja; $i$ neka ne pokazuju ukrase svoje osim onoga što je ionako spoljašnje... . (Kur'an, En-Nur, 31.)

Kur'an daje propise i za porodično, kućno ponašanje:

"O vjernici, neka od vas u tri slučaja zatraže dopuštenje da vam uđu oni koji su u posjedu vašem i oni koji još nisu spolno zreli: prije jutarnjeg namaza i kada u podne odložite odjeću svoju, i poslije obavljanja noćnog namaza. To su tri doba kada niste obučeni, a u drugo doba nije ni vama ni njima grijeh, ta vi jedni drugima morate ulaziti. Tako vam Allah objašnjava propise! A Allah sve zna i Mudar je." /58/ "A kad djeca vaša dostignu spolnu zrelost, neka onda uvijek traže dopuštenje oni stariji od njih; tako vam Allah objašnjava propise Svoje! A Allah sve zna i Mudar je." /59/ (Kur'an, En-Nur, 58-59.) 
I ne samo da Šerijat daje kompletna rješenja, nego čak i prevenciju. Konvencionalna i savremena zakonodavstva dozvoljavaju pornografiju, ekshibicionizam, nepristojno, izazovno oblačenje ili razgolićenost što je upravo poziv na nemoralnost.

Nasuprot toga, šerijatsko zakonodavstvo propisuje oblačenje i pristojnost kao najpraktičnije sredstvo za zaštitu od mobinga i seksualnog iskorištavanja. Kur'an je od Dragog Boga, Njegova milost ljudima i dar da imaju program po kojem će živjeti. To je najbolji mogući sistem življenja za čovjeka u vremenskom totalitetu dunjaluka $i$ ahireta.

\section{Preveniranje djela i aktivnosti koje odvode nemoralu i bludu}

Mnogobrojna su djela, postupci, aktivnosti i sredstva koja vode ka moralnoj izopačenosti a tretiraju se kao normalno, slobodno ponašanje na zapadu i umjesto da se radi na preventivi nemorala, mobinga, bluda i sl. radi se upravo na njihovoj suprotnosti:

1. Namjerno, javno, izazivanje seksualnih strasti razgolićavanjem, pokazivanjem ženskih ukrasa, fizičkih ljepota, draži, skretanje pažnje zveketom nakita i obuće.

Uzvišeni kaže:

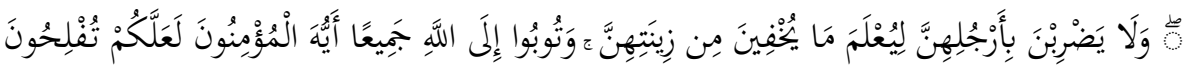
I neka ne udaraju nogama svojim da bi se čuo zveket nakita njihova koji pokrivaju. I svi se Allahu pokajte, o vjernici, da biste postigli ono što želite. (Kur'an, En-Nur, 31.)

Ez-Zamahšeri objašnjava: "Značenje riječi razgolićavanje je namjerno pokazivanje onoga što treba sakriti.” Uzvišeni kaže:

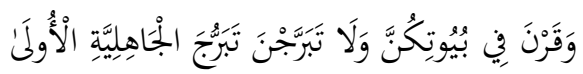

U kućama svojim boravite i ljepotu svoju, kao u davno pagansko doba, ne pokazujte... (Kur'an, El-Ahzab, 33.)

2. Oblačenje providne odjeće koja pokazuje ženske draži i izaziva mušku pohotu, njena promocija u medijima, javno kretanje i pojava $u$ takvoj odjeći pred muškarcima koji joj nisu mahremi. Poslanik, a.s., upozorio je na razgolićene žene, a u njih spadaju i one koje oblače providnu odjeću: 


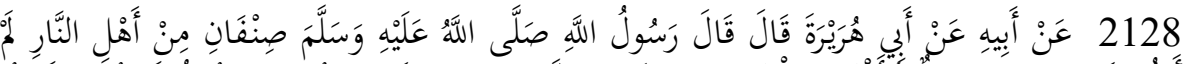

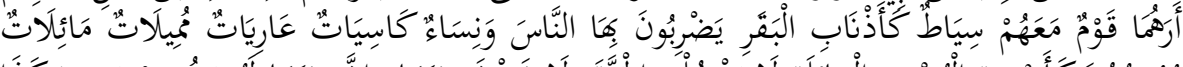

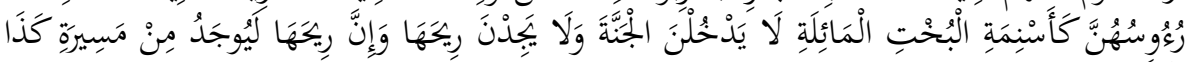

Dvije vrste su stanovnika vatre koje ne vidjeh: Ljude koji bičevima poput kravljih repova narod udaraju $i$ polugole žene obučene $u$ providno, grješnice, Bogu nepokorne koje i druge nepokornosti podučavaju, glave su im kao grbe deva naherenih. One u džennet neće ući niti će osjetiti njegov miris koji se osjeća na toliku doljinu. (Muslim, 2128.)

3. Ženi je zabranjeno izaći iz kuće izazovna i namirisana, da izazove pozornost pošto su Ebu Davud, Tirmizi i Nesai sa ispravnim lancem prenosilaca zabilježili predaju u kojoj se navodi da je Allahov Poslanik, a.s., kazao:

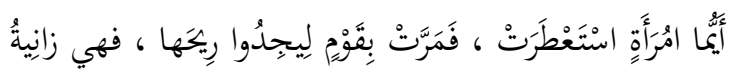

Koja god se žena namiriše pa u prolasku pored ljudi osjete njen miris, računa se kao da je bludnica.

Hadis su zabilježili: Ahmed br.: (19578., 19711., 19747.), Ebu Davud br.: 4173., Tirmizi br.: 2786., Nesai br.: 9424., Ibni Huzejme br.: 1681. i mnogi drugi. Izraz računa se bludnicom, upotrijebljen je na način kao što je upotrijebljen izraz u hadisu: Oko čini blud, a njegov blud je pogled. Neki komentatori navode da žena tim činom privlači pažnju i pohotu ljudi koji je onda gledaju, a onaj ko je zagleda čini blud pogledom, tako da je time i skretanjem pažnje na sebe u najmanju ruku ako ništa drugo, uzrokovala blud oka i time zgriješila.

4. Razgolićavanje, otkrivanjem stidnih dijelova tijela koji su naznačeni $u$ ajetu pa makar i malog dijela, glave, prsa, lakata, potkoljenica itd. Allah, dž.š., kaže: Neka vela svoja spuste na grudi svoje. Čak i nepoželjnim i neatraktivnim staricama kojima je Allah, dž.š., olakšao kod pokrivanja, nije dozvoljeno pokazivanje ženskih ukrasa. Uzvišeni kaže:

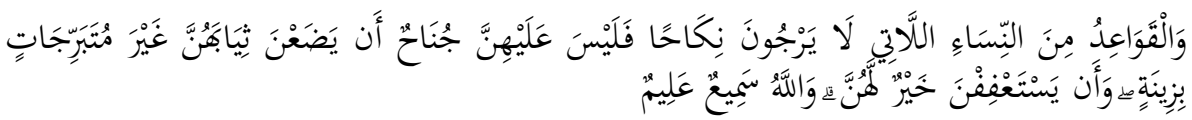

A starim ženama koje više ne žude za udajom nije grijeh da odlože ogrtače svoje, ali ne pokazujući ona mjesta na kojima se ukrasi nose; a 
bolje im je da budu krjeposne. Allah sve čuje i zna. (Kur'an, En-Nur, 60.)

5. Rukovanje $i$ dodirivanje ženskog tijela žena koje nisu rodice $i$ računaju se strankinjama, a $i$ obratno. Od Aiše, r.a, prenosi se (Buharija, 6788.) da je rekla:

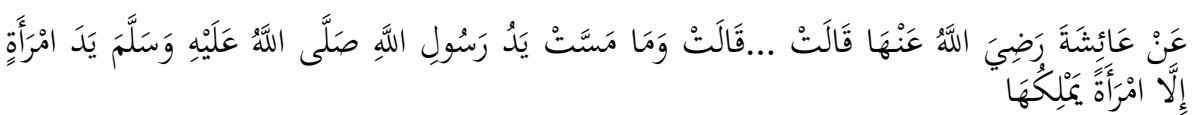

Poslanikova, a.s., ruka nije dodirnula ruku žene, osim njegovih žena.

Ipak, po ovom pitanju postoji pravni razlaz. Izrazita većina uleme smatra da je to zabranjeno. Od imama Ahmeda prenosi se i stav da je to pokuđeno, općenito, dok neki savremeni učenjaci to dozvoljavaju uz uvjet bezbjednosti i nepostojanja pohote i želje za ženom i da se zgriješi.

6. Zajedničko spavanje djece. Od zabranjenih stvari je i miješanje djece u postelji, bila ona muška ili ženska, zbog vjerodostojnog hadisa:

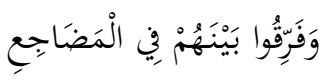

Razdvojite djecu u posteljama

Dužnost je paziti na ovo kada djeca dostignu desetu godinu. Allah, dž.š, naredio je čednost i zabranio stidna mjesta (osim u bračnoj vezi), naredio je i sprečavanje svih puteva i ulaza na koje šejtan prilazi čovjeku, dolazi mu i može s tih pozicija da negativno djeluje na njega i navodi ga na griješenje. Na taj način islamski pravni sistem, prije svega, preventivno djeluje.U tom smislu došao je Kur'anski propis koji muškarcima i ženama naređuje obaranje pogleda, zatim propis koji nalaže traženje dozvole za ulazak u odaje i prostorije roditelja od strane kućne služinčadi i rođene djece. Žena je podučena najljepšim načelima ponašanja i naređeno joj je pokrivanje stidnih dijelova tijela pred strancima. Propisani su i adabi ulaska u kuću i traženja dozvole, te načina razgovora sa tuđim ženama u nuždi. Bliski srodnici (koji se ne mogu vjenčavati) izuzeti su iz ovih zabrana u ovim pravilima, a sve to da bi se spriječili putevi koji vode nedoličnom ponašanju. 


\section{Zaključci}

Porodično pravo predstavlja skup pravnih normi kojima se reguliše porodica i odnosi koji nastaju prilikom formiranja porodice, veze muškarca i žene, njenog trajanja ili prestanka postojanja.

Teoretičari prava u savremenoj islamskoj kulturi i civilizaciji uobičajili su za regulativu koja se tiče braka, razvoda, testamenta i nasljeđivanja, termin porodično pravo, iako je, ranije, $\mathrm{u}$ islamskom fikhu sve ono što reguliše porodične odnose, nazivano posebnim imenom/naslovom, poglavljem, kao što je poglavlje o braku, razvodu i sl.

Uticajem konvencionalnog zakonodavstva i u islamskom pravu došlo se do upotrebe termina islamsko porodično pravo, početkom dvadesetog vijeka, nakon kolonizacije arapskog islamskog svijeta od strane Engleske i Francuske. U prvoj polovici dvadesetog vijeka, dolazi do upotrebe termina porodično pravo, posebno u Iraku, da bi se na kraju $\mathrm{u}$ islamskom svijetu došlo do izrade posebnog porodičnog zakona 1959.g.

Bračno pravo uređuje pitanja sklapanja, dejstva i prestanka braka. U posljednje vrijeme, ovdje spadaju i pitanja vezana za vanbračnu zajednicu, a u novije doba pod utjecajem i diktatom međunarodnih faktora pod izlikom zaštite ljudskih prava, LGBT osoba i nekih drugih diskriminiranih grupacija traži se uskladivanje postojećeg zakonodavnog okvira u BiH sa Zakonom o zabrani diskriminacije koji je donesen 2009. godine što se reflektuje na pitanje $i$ pokušaje izjednačavanja istospolnih brakova sa biseksualnim.

Dakle, kod nas kao i u zemljama regiona, vidljiv je utjecaj međunarodne zajednice i njenih pravnih normi na lokalna zakonodavstva, kao i utjecaj politike i globalnih evroatlanskih integracija nametanjem novih zakonskih rješenja koji u nekim slučajevima zadiru u samu bit i srž dosadašnjih pravnih shvatanja i terminoloških određenja, protive se uvriježenim vjerskim i moralnim normama stanovništva, bez obzira na vjeru i naciju. To je slučaj posebno u ovoj grani pravne znanosti.

Općepoznati međunarodni akti koji su izvori porodičnog prava, preuzeti su gotovo bez ikakvih izmjena u zakonodavstvo zemalja našeg regiona-okruženja. 
U savremeno doba mnoga ,napredna" zapadna zakonodavstva imaju intenciju da idu za dozvolom svih nastranosti i perverzija koje prate moralni pad zapadnog čovjeka. Time zapadna civilizacija narušava univerzalne porodične vrijednosti, moral, brak i instituciju braka koja je prirodni i normalni uvjet za opstanak čovjeka na zemlji i njegovu reprodukciju.

Historijski gledano, krajem šestog stoljeća po rođenju Isaa, a.s., usred džahilijetskog mračnjaštva i odnosa spram žene u tadašnjim pravnim običajima Arapskog poluotoka, dolazi Božija objava koja će dati ženi njena prava shodno njenom dostojanstvu i njenoj ulozi kao ljudskog bića. Reformska načela sa kojima je došao islamski sistem, a tiču se statusa žene i njene uloge u društvu, ogledaju se u mnogobrojnim društvenim i porodičnim aspektima i mogu se konkretizovati kroz socijalno/društveni, humani/ljudski i pravno/šerijatski aspekt.

To je bio revolucionarni napredak i ustrojavanje Božanskog sistema koji daje svim adresatima njihova prava bez manjkavosti, a u pogledu žene dokida nepravdu i poniženje kojima je ona bila izložena tokom cijele ranije historije čovječanstva.

Uzvišeni, dragi Bog najbolje zna šta odgovara čovjeku i ženi, njihovoj ljudskoj prirodi, kao i to šta je najbliže pravdi koja treba da zadovolji sve strane.

Kako bi razumjeli revolucionarno poboljšanje statusa žene, kojeg je žena dobila islamom, moramo naglasiti koliko je žena bila obespravljena u paganskom, džahilijetskom, predislamskom društvu u kojem su predislamski Arapi imal i jedan barbarski, paganski običaj zakopavanja žive ženske djece, prakticiran sve do pojave Muhammeda, a.s., koji je poslan da to novim pravednim, božanskim zakonodavstvom zabrani, uredi položaj i status žene na najbolji i najpravedniji način.

Žena je po svojoj prirodi stvaranja jedna od dvije ambivalentne ljudske jedinke čija ravnopravnost $u$ principu izvire iz jednakosti njihovog pripadanja ljudskom rodu, istoj vrsti, a njihove međusobne razlike izviru iz mudrosti Uzvišenog Kreatora, koji im dade različite uloge kao dva spola sa specifičnim mogućnostima i funkcijama.Zbog toga, u islamu imaju i specifične nerazdvojne uloge koje se nužno dopunjuju, za koje su svako od njih fizički, psihički i emocionalno dizajnirani i predodređeni od mudrog Kreatora. 
Islamska doktrina ne optužuje nikoga za tuđi grijeh i prvo što je urađeno u statusu i oslobađanju žene jeste njeno slobađanje od prokletstva iskonskog grijeha. Uzvišeni to proklamuje u Kur'anu na više mjesta $u$ različitim kontekstima, ali uvijek po principu samo lične odgovornosti svakog pojedinca i pravila: Što god ko uradi, sebi uradi, i svaki grješnik će samo svoje breme nositi. (6:164.)

Radost dobijanja djeteta, $\mathrm{u}$ islamu se proslavlja akikom u kojoj se iz zahvalnosti dragom Bogu, po pritvrđenom sunnetu, kolje i prinosi žrtva akike, kurbana i žrtve dragom Bogu kao najviši vid zahvalnosti na daru muškog a isto tako i ženskog djeteta.

Briga za ženu kao kćerku, suprugu i majku došla je kroz mnogobrojne kur'ansko-hadiske tekstove iz kojih se razumiju prava i povlašteni položaj i status žene koji joj daje sistem islama praveći balans između njene ljudske prirode i prava koja ona uživa.

Islam dokida običajni, izrabljivački i nepravedni odnos prema ženi kao ljudskom biću, dokida pravne običaje diskriminacije žene u predislamskom društvu, žena dobija pravo vlasništva, zatim obavezno, diskreciono pravo vjenčanog dara (mehr), kao nagradu ili vid materijalne sigurnosti ulaska u brak, što govori o visokoj vrijednosti božanskog sistema Šerijata.

Te vrijednosti koje islam dade ženi nisu poznavali mnogi pravni sistemi ni čitav milenij poslije pojave islama. Žena je i u našim krajevima bila obespravljena hiljadu godina nakon što ju je islam oslobodio i dao joj prava koja zaslužuje. Dr. Vojislav Spaić raspravlja o utjecaju šerijatskog prava na nasljednopravne običaje u Bosni i Hercegovini i navodi da se, s punim pravom, može reći da su žene bile isključene iz nasljeđivanja nekretnina te konstatira da ne smijemo zaboraviti da su pravni običaji koji dozvoljavaju ženama nasljedstvo vlastite zemlje nastali (tek) pod utjecajem turskog zakonodavstva.

Kod Arapa koji su prakticirali višeženstvo i bili direktni objekat zadnje Božije Poslanice, kao što je bio slučaj i kod nekih drugih predislamskih naroda, praksa poligamije nije bila ograničavana važećim pravnim običajima, pa je islam ograničio poligamiju na najviše četiri žene, u isto vrijeme, a dozvola poligamije bila je pod uvjetom da se bude pravedno prema ženama, inače je dozvoljeno imati samo jednu ženu. 
Islam je pokazao i brigu za najranjiviju žensku kategoriju, za koju Uzvišeni Allah daje posebne norme u Kur'anu, posebno za njih brine, a to su sirote - jetimi, sirotice koje su pod skrbništvom i predstavljaju lahak plijen skrbnika.

Savremena društva su se našla u situaciji da tragaju za rješenjima kako suzbiti mobing i seksualno uznemiravanje žena u otvorenom društvu, posebno u radnom okruženju. Primjećuje se da zakonska rješenja u ovoj oblasti, do kojih se došlo u ovo savremeno doba, kao da su prepisana iz normi Kur'ana, međutim, uzeta su jednostrano bez nekih drugih, nužnih, moralnih normi koje ih čine efikasnim u praksi. S pravom možemo kazati da zakonodavstva najvećih ekonomskih zapadnih sila, u ovoj oblasti, kaska za Kur'anskim rješenjima preko 1400 godina, jer radi se o jednostranom rješenju i pokušaju zaštite samo ženske populacije i samo u radnom okruženju gdje su one najnezaštićenije.

Ova zakonodavstva ne propisuju sredstva koja mogu pridonijeti zaštiti, nego dozvoljavaju otkrivanje i pokazivanje golotinje, sve moguće puteve i reklamu toga od slobodnog ponašanja, otkrivanja, pornografije, bluda itd., što sve u krajnjoj konsekvenci pomaže i vodi u mobing i uznemiravanje, a onda krhkim zakonskim rješenjima pokušavaju to suzbiti.

Mnogobrojna su djela, postupci, aktivnosti i sredstva koja vode ka moralnoj izopačenosti a tretiraju se na zapadu kao normalno, slobodno ponašanje i umjesto da se radi na preventivi nemorala, mobinga, bluda i sl. radi se upravo na njihovoj suprotnosti. Allah, dž.š, naredio je čednost i zabranio stidna mjesta (osim u bračnoj vezi), naredio je i sprečavanje svih puteva i ulaza na koje šejtan prilazi čovjeku, dolazi mu i može $\mathrm{s}$ tih pozicija da negativno djeluje na njega i navodi ga na griješenje. Na taj način islamski pravni sistem, prije svega, preventivno djeluje, pa tek onda rigoroznim, pa i egzemplarnim sankcijama.

\section{Literatura}

1. El-Kur'anu-l-kerim, Mushaful-Medinetin-Nebevijjeh (Kur'an Časni, medinska verzija Mushafa), (Mudžemme'ul-melikFehd, 1405.h.),

2. Korkut Besim, Kur'an s prevodom (Štamparija kralja Fehda, S. Arabija, Medina, 1412. h.), 
3. Ahmed b. Muhammed b. Hanbel Eš-Šejbani, Musned (Muesseseturrisale, 1421/2001),

4. Bedruddin El-'Ajni, 'Umdetu-l-kari'i šerh Sahihul-Buhari, (Darul-fikr, Bejrut),

5. Ebu-HamidMuhammedel-Gazali; El-Mustesfamin 'ilmi-l-usul. Bejrut:

Daru-1-'ulumi-1-hadise. Muhibbullah b. 'Abduššekur; Fevatihurrehamutbišerhmusellemis-subut. Daru-1-'ulumi-1-hadise.

6. Ez-Zejle'i; Nasbur-rajetiliehadisil-hidaje. Daru-1-hadis.

7. IbnDžerirEt-Taberi, Džami'u-l-bejanfite'viliaji-l-Kur'an, (Daru-l-Fikr, 1984.),

8. Ibn Hadžer El-'Askalani, Fethul-Bari bišerh Sahihu-l-Buhari, (Darurrejjan lit-turas, Kairo, 1987.),

9. Ibn Kesir, Tefsir Ibn-Kesir, skraćeno izdanje, Izabrao najispravnije verzije Muhammed Nesib er-Rifa'i, (Visoki saudijski komitet, Sarajevo, 2000.),

10. IbniTejmije, Medžmu’ufetava, (IzdanjekraljaFehdab. 'Abdulaziza, 1398.),

11. Ismai'l b. Muhammed El-A'džluni, Kešful-hafa'i ve muzilul-ilbasi a'mmaštuhire minel-ehadisi a'la elsinetin-nas (Darul-kutubil-masrijje),

12. Muhammed b. Ahmed el-Kurtubi, El-Džamiu' liahkamil-Kur'an, (Daru ihjait-turasil-'Arebi, Bejrut, Libanon, 1985.),

13. Muhammed Nasirud-din el-Albani, Irvaul-galil, (el-Mektebul-islami, 1399/1979.),

14. Muhammed b. Ismai'l El-Buhari; (1414/1993). Sahih. Daru Ibni Kesir.

15. Muslim b. El-Hadždžadž El-Kušejri En-Nejsaburi; Sahihu Muslim. Daru ihjail-kutubil-a'rebijje.

16. Spaić, Vojislav; (1967.). NasljednopravniobičajiuBiHnakonAustroUgarskeokupacije. Sarajevo: AkademijanaukaiumjetnostiBiH, knjiga XXXII., Odjeljenje društvenih nauka, knjiga 11., Sarajevo, 1967.

17. Vehbe ez-Zuhajli; (1984). El-Fikhul-islamijju ve edilletuh. Damask: Darul-fikr.

18. Vizaretul-evkaf veš-šuunil-islamijje, El-Mevsu'atul-fikhijje, (Vizaretulevkaf veš-šuunil-islamijje - Kuvejt, 1404/1983.)

\section{Internet:}

19. https://ar-ar.facebook.com/Astawso.Belnesaa2.../51286493214464... pristupljeno 10, novembar, 2017. 
20. www.novihorizonti.ba/poligamija-visezenstvo/, pristupljeno, 18. novembra 2017.

21. https://id.scribd.com/document/.../Dr-Zakir-Naik-Poligamija-u-Isla..., posjećeno, 18. novembra, 2017.

22. Dnevni Avaz 28. februara 2008. 


\section{Muharem Štulanović, PhD \\ University of Bihac \\ Islamic Pedagogical Faculty \\ ebuseba@hotmail.com}

Original scientific article

\section{FAMILY LAW AND THE REVOLUTIONARY CONTRIBUTION OF ISLAM TO THE STATUS OF WOMEN}

\section{Abstract}

Family law can be treated as a branch of positive law and as a separate, independent part of the legal science.

Family law is a set of legal norms which regulate the family and relationships between family members, that is relationships that are formed when forming a family, its duration or cessation of existence. These relationships arise from the foundation of the relationship between a man and a woman, birth and forms of kinship that result from that connection.

Law theorists in Islamic culture and civilization commonly use the term of family law for the regulation of marriage, divorce, testament, and inheritance, although in Islamic Figh, everything that is regulated by family relations has previously been called by a personal, special name such as the chapter of marriage, divorce, etc.

Islam has brought about a revolutionary improvement in the status of women in terms of the application of human rights and the overthrow of the previous customs that have been discriminatory, because Allah Almighty has bestowed and enriched the human race, both of its parts, female and male, whose relations $\mathrm{He}$ regulated with regulations that are distinctive by its specificities and values.

The principles of reform that came with the Islamic system, especially those concerning the status of women and its role in society, are reflected in many aspects and can be concretized through the social, human and legal/Sharia aspects.

Keywords: family law, Islamic family law, women's status, family, marriage, extramarital union, bisexual and same-sex marriages, women's rights, discrimination against women. 


$$
\begin{aligned}
& \text { الأستاذ الدكتور محرم شتولانوفيتش } \\
& \text { جامعاة بيهاتش } \\
& \text { كلية التربية الإسلامية } \\
& \text { ebuseba@hotmail.com }
\end{aligned}
$$

\section{قانون الأسرة وإسهام ثوري للإسلام لمنزلة المرأة}

\section{الخلاصية}

يمكننا تناول موضيوع قانون الأسرة باعتباره فرعاً من فروع القانون المطبق أو جزءًا خاصًا مستقلاً لعلم القانون. يمثل قانون الأسرة مجموعة من الأحكام التي تنظم الأسرة والعلاقات بين أفراد

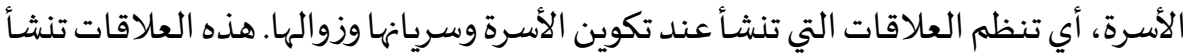
من خلال إقامة العلاقة بين الرجل والمرأة والأولاد والأنواع من القرابة التي تنبثق من تلك الك العلاقة.

المنظرون القانونيون في الثقافة والحضارة الإسلامية اعتادوا استخدام مصطلح

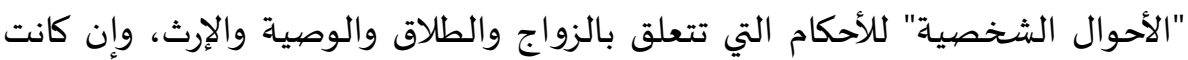

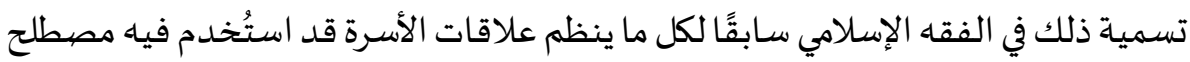
خاص باه، مثل باب الزواج، باب الطلاق وغيرهما.

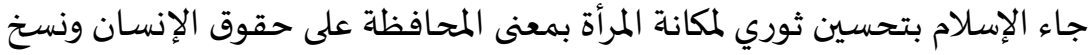

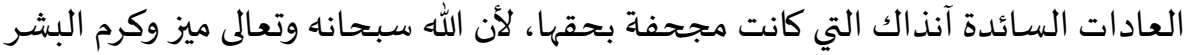

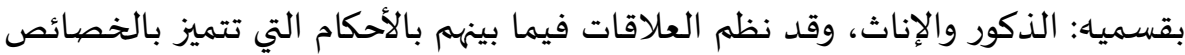
والفضائل.

المبادئ الإصلاحية التي جاء بها النظام الإسلامي، خاصة تلك التي تتعلق بمكانة المرأة

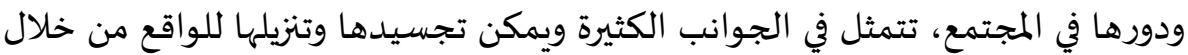
الجانب الاجتماعي والإنساني والقانوني أو الشرعي.

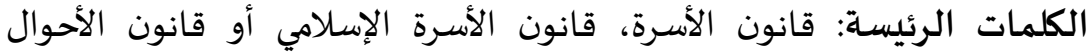

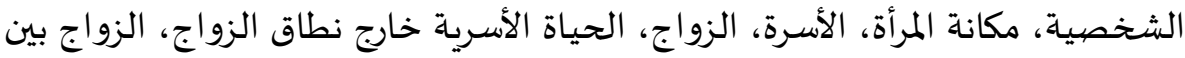
مزدوجي التوجاء الجنسي أو بين ذوي الجنس الواحد، حقوق الأسرة، المرأة، تمييز المرأة. 